\title{
Aid, Growth and Devolution
}

\author{
Christian Lessmann \\ Gunther Markwardt
}

CESIFO WORKING PAPER NO. 2805

CAtegory 6: Fiscal Policy, Macroeconomics AND Growth

SEPTEMBER 2009

An electronic version of the paper may be downloaded
- from the SSRN website: $\quad$ www.SSRN.com
- from the RePEc website:
- from the CESifo website: 


\title{
Aid, Growth and Devolution
}

\begin{abstract}
This paper examines whether the federal structure of aid-receiving countries matters in explaining aid effectiveness. Following the decentralization theorem, the devolution of powers should increase aid effectiveness, since local decision-makers are better informed about local needs. At the same time, decentralization has reverse effects, e.g., through coordination problems, excessive regulation, administrative costs and local capture. Using panel data for up to 60 countries, we find that aid is less effective or even harmful in decentralized countries. Our results imply that donor countries should carefully consider how both anti-poverty instruments - financial assistance and decentralization - work together.
\end{abstract}

JEL Code: O10, O20, O40, H70.

Keywords: foreign aid, growth, decentralization.

\author{
Christian Lessmann \\ Technical University Dresden \\ Faculty of Business and Economics \\ Chair of Public Economics \\ 01062 Dresden \\ Germany \\ christian.lessmann@tu-dresden.de
}

\author{
Gunther Markwardt \\ Technical University Dresden \\ Faculty of Business and Economics \\ Chair of Public Economics \\ 01062 Dresden \\ Germany \\ gunther.markwardt@tu-dresden.de
}

This version: July 2009

We are grateful to Marcel Thum, Massimo Bordignon, Thiess Büttner, Jenny Ligthart, Eckhard Janeba, Jürgen von Hagen and the participants and the 65rd congress of the International Institute of Public Finance (2009) in Cape Town for many useful comments. Moreover, we would like to thank André Seidel for helping us in data collection and preparation. Financial assistance from the DFG is gratefully acknowledged. 


\section{Introduction}

The majority of developing countries depend heavily on external resources. In some of the poorest countries, such as Timor-Leste or the Democratic Republic of Congo, the share of development aid in gross national income is above 50\% [Worldbank (2006)]. Since 1960, member countries of the OECD's Development Assistance Committee (DAC) have spent almost 2 trillion US dollars of official development assistance (ODA). In recent years, ODA amounts to roughly 100 billion US dollars per year.

In light of these enormous figures, there has been an increasing interest in the efficiency of foreign aid. The question is whether aid promotes economic development, or whether aid has undesirable side effects making it ineffective. In the past 30 years, a large number of studies investigating the aid-growth nexus have been published. Despite the enormous effort researchers have invested in this issue, there is still no consensus. Since the literature presents a mixed picture of a direct impact of aid on growth, numerous studies have begun to focus on the conditions under which aid is effective. One issue that has been neglected in this literature is the role of the federal structure of aid-receiving countries. This is quite surprising, as national and supranational development agencies consider the devolution of powers as major part of their anti-poverty programs. For example, 12\% of World Bank projects completed between 1993 and 1997 involved decentralizing responsibilities to lower levels of government [Litvack et al. (1998)]. In 2006, more than 19\%, or 4.5 billion dollars, of the World Bank budget was spent on projects involving decentralization [Development Committee (2006)].

The reason for considering decentralization in anti-poverty programs is that it might have positive effects on economic development and growth [Oates (1993)]. Decentralization brings the government closer to the people so that local officials are better informed on the local needs, and are thus more capable to provide the optimal mix of local policies. This increase in efficiency contributes to economic growth [Oates (1972)]. The efficiency argument also plays a role in the case of aid assignment. If local bureaucrats have better information of local needs, they might also have an advantage in selecting the most effective development projects to be financed by foreign aid. Thus, decentralization should increase aid effectiveness.

There are also arguments for a negative impact of decentralization on aid effectiveness, e.g. coordination problems, excessive regulation, administrative costs, and local capture. For example with the capture of local governments, there is a tendency for the local government to provide excessive services to the local elite at the expense of the general public [Bardhan (2002), Bardhan and Mookherjee (2006)]. Decentralization might therefore increase corruption and cronyism [Lessmann and Markwardt (2008)]. If we transfer this finding to the case of aid assignment in developing countries, it means that aid is spent less effectively in decentralized countries in comparison to centralized countries.

In light of these opposing arguments, the aim of our paper is to investigate aid effectiveness subject to the federal government structure in target countries. Table 1 provides data showing considerable 
differences between aid-receiving countries with respect to the degree of decentralization, the share of aid in GDP, and their economic development. For instance, countries of Latin America and the Caribbean have, on average, a low degree of expenditure decentralization (14.0\%), while countries in Europe and Central Asia have a higher degree of decentralization (24.3\%). Even though both regions have received a similar amount of foreign aid in relation to GDP, Latin American countries have grown much faster.

Table 1: Stylized facts: Aid, Growth and Decentralization around the world

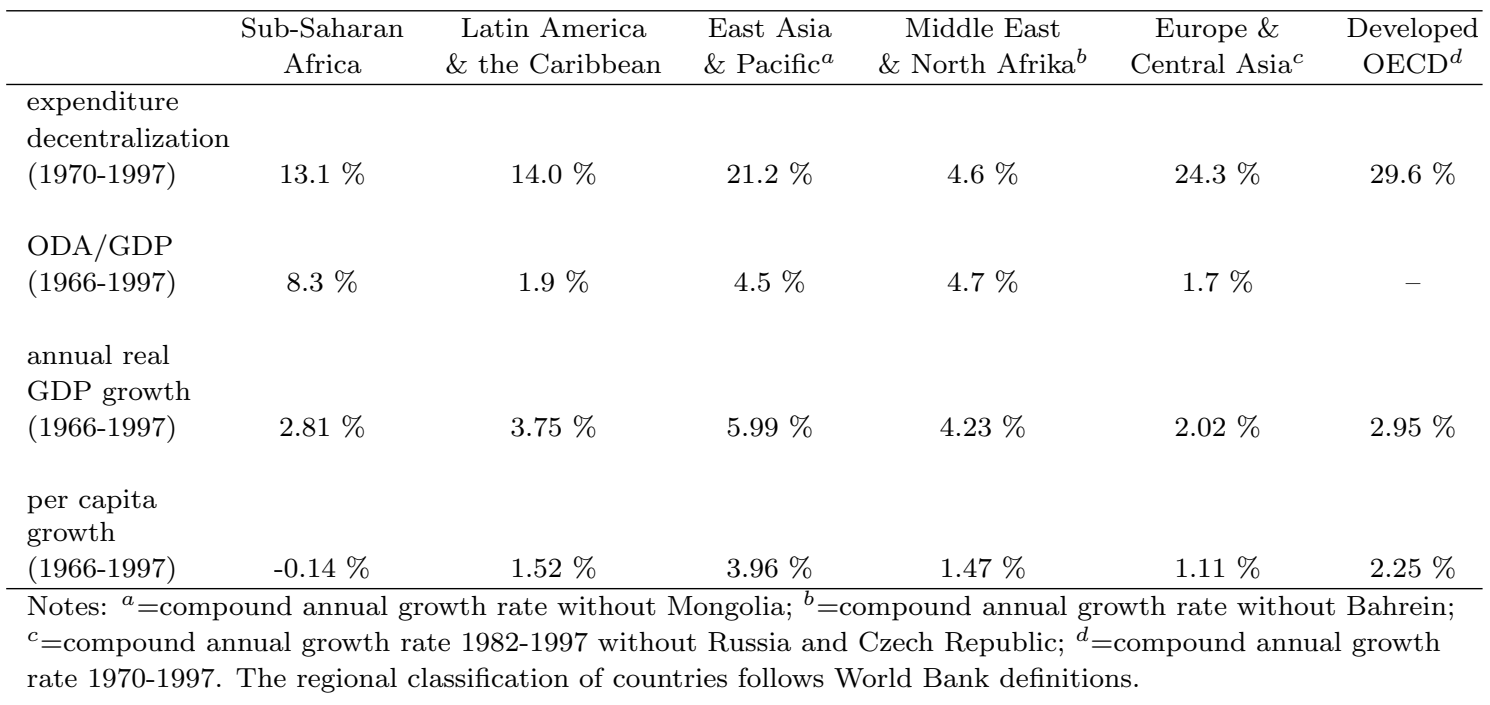

Our brief theoretical considerations and the presented data suggest that the effectiveness of foreign aid may depend on the devolution of powers. To answer this research question, we estimate a commonly-used growth model based on a panel data set of 60 developing countries, covering the period 1966-1997. In contrast to previous studies, we don't focus on the interaction between aid and 'good policy'. Instead of that we focus on relationship between aid and decentralization on growth. Our main finding is that foreign aid has no significant impact on growth, decentralization has a significant positive impact on growth, and that aid is more effective in centralized countries. Furthermore, we show that decentralized countries receive more development assistance, although our results cast doubt on the appropriateness of decentralization as part of development programs.

The remainder of the paper is organized as follows. In section 2, we provide an overview of the theoretical arguments concerning the relationship between aid, growth, and the role of decentralization. Section 3 surveys the existing empirical studies on the aid-growth relationship, as well as the literature on growth and decentralization. In section 4 we conduct our econometric analysis. Finally, we sum up our findings and conclusions in section 5. 


\section{The Theoretical Link between Growth, Aid, and Decen- tralization}

The theoretical justification for foreign aid is based on three classes of so-called 'gap models.' The well-known Harrod-Domar growth model assumes an excess supply of labor in developing countries, decreasing the productivity of capital. Foreign aid helps to increase domestic savings or directly increase productivity of capital-promoting economic growth [Domar (1946)]. In Chenery and Strout's dual gap model, foreign aid promotes development by adding to domestic savings and to foreign exchange availability [Chenery and Strout (1966)]. Aid payments help to either close the gap between savings and investment, or the gap between export and import, which occur in developing countries because of limited resources. In addition to the savings and investment gap, Bacha (1990) asserts that developing countries' governments have weak revenue-raising capacities, causing a third fiscal gap. Foreign aid may close this gap and thus stimulating investments and economic growth.

Friedman (1958) and Bauer (1972) question these positive effects of aid. They argue that foreign aid hampers economic growth because it will strengthen the power of predatory governments and thus undermine the emergence of a private sector. Other arguments against a positive effect of aid are related to its amount and nature. For example, aid is spent because people in rich countries have pity on those in poorer countries because famine, war, eviction, and natural disasters. ${ }^{1}$ These donations help developing countries to push their economy back to their long-run steady state growth path, but not necessarily beyond that. Other examples for ineffective aid include foreign assistance motivated by geostrategic and political reasons. During the Cold War, western countries, as well as communist Warsaw Pact countries, tried to influence the political elite in developing countries, using foreign aid payments to implement their respective ideologies [Alesina and Dollar (2000) and Wood (2005)]. These aid payments often ended in incumbents' pockets and were hardly able to promote economic growth [Alesina and Weder (2002)]. Nowadays, we can still observe such patterns by donor states. For example, Nigeria receives the largest amount of ODA (debt reliefs) in the world with 10.8 billion U.S. dollars (2007), and it is not farfetched to believe that the recent rise in oil prices and corresponding Nigerian oil deposits have played an important role in this context. As this brief discussion shows, aid might have a positive impact on economic development if donors and/or receivers are benevolent, but aid can also be an obstacle for growth if political or personal interests are involved.

Both donor countries and international development agencies consider decentralization as an important element in their anti-poverty programs. The main argument in favor of decentralization is that the transfer of powers to sub-national governments increases public sector efficiency, thus promoting economic development [Oates (1993)]. Decentralized authorities are much better informed regarding local needs, and can provide the economically-efficient quantity and quality of local public goods. Especially in the case of a federation with heterogeneous regions, decentralized

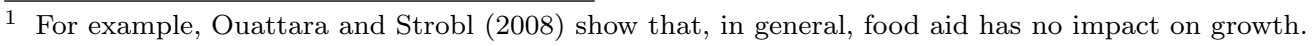


officials are in a better position to meet local demands [Oates (1972)]. Another argument in favor of fiscal decentralization is the role of local governments in preserving markets [Weingast (1995)]. The idea is that the government acts as monopolist and has the power to exploit the private sector [Shleifer and Vishny (1993)]. In a decentralized setting, local governments compete on mobile factors. This fiscal and institutional competition limits the government's ability to extract rents, enhancing economic efficiency and thus economic growth.

Following these arguments, foreign aid and decentralization may contribute to economic development separately. The question is whether this result is maintained when we combine both instruments. The efficiency argument above can also be made in this context. Local governments are better informed regarding local demands and are thus able to allocate aid in the most useful projects. If foreign aid is aimed at overcoming the shortness of local public goods - such as infrastructure, schools, or health care - then decentralization should increase efficiency of public services and thus aid effectiveness. Also, the competition argument is relevant in light of the limited amount of aid available in developing countries. Sub-national jurisdictions have an incentive to perform well in exchange for aid payments, thus increasing aid effectiveness. From this point of view, decentralization should increase aid effectiveness.

However, several observers dismiss the positive effects of decentralization for developing countries. Swaroopa et al. (2000) analyze the fungibility of aid in federal systems and find that aid merely substitutes for spending that the government would have undertaken anyway. Moreover, aid received by sub-national governments decreases central government transfers in a similar amount. From a political economy perspective, Prud'homme (1995) argues that in decentralized countries there are more opportunities for corruption at the local level because local politicians and bureaucrats are more likely to be subject to the pressing demands of local interest groups. In addition, local decision makers usually possess more discretionary powers than national officials, increasing the possible negative effects of decentralization. In the same vein, Tanzi (1996) argues that local officials live closer to the citizens, and this contiguity leads to a higher impact by local interest groups on local policy outcomes. Bardhan and Mookherjee (2006) provide a formal analytical framework to investigate the effects of decentralization on public service provision in developing countries considering the capture of local governments. With local capture, with regard to the elite receiving a larger weight in the local government's welfare function, there is a tendency for the local government to provide excessive services to the local elite at the expense of the non-elite [see also Bardhan (2002)]. ${ }^{2}$ This problem might also occur if local bureaucrats decide on the allocation of foreign aid to local development projects. Therefore, aid might be less effective in decentralized countries due to corruption and cronyism.

The quality of bureaucrats is also an important factor for the relationship between aid, growth, and decentralization. Prud'homme (1995) and Tanzi (1996) argue that central government bureaucracies are likely to attract more qualified people because they offer better career opportunities and higher salaries [Brueckner (2000)]. If qualified individuals are abundant, as in most industrial

\footnotetext{
2 An empirical study by Lessmann and Markwardt (2008) shows that decentralization has indeed a negative impact on corruption if the monitoring of bureaucrats does not work, which is the case in most aid-receiving countries.
} 
countries, sub-national governments may have staff that is as qualified as those in national governments. In developing countries, however, educational standards are low and qualified human capital is scarce. Therefore, under decentralization sub-national government, officials entrusted with aid disposition may be less qualified for this task than central bureaucrats in reducing aid effectiveness. As the discussion in this section shows, our hypothesis that aid effectiveness depends on the federal government structure is well-grounded in the theoretical literature.

\section{A Survey of Aid-Growth and Decentralization-Growth Studies}

Since the 1970s, the impact of foreign aid on growth has been studied extensively. Our literature survey is based on 29 studies published in high-ranking journals between 1972 and 2008. ${ }^{3}$ Table A. 6 in the appendix summarizes all these studies with respect to the data, methodology, estimation approach, and main results. We briefly discuss some of the most influential contributions.

Papanek (1973) was the first study to apply a regression analysis to cross-country data. He found a positive and significant relationship between foreign aid and growth. In the subsequent 20 years, several studies were carried out supporting these findings [e.g., Dowling and Hiemenz (1982) and Levy (1988)] or finding no significant relationship between aid and growth [e.g., Voivodas (1973) and Mosley et al. (1987)].

Boone (1996) was the first study to analyze panel data of a wide range of countries. In contrast to most of the existing studies, Boone used indicators for human development to evaluate aid effectiveness, finding no significant effect. He concludes that most aid goes to consumption, but that higher consumption did not benefit the poor. Svensson (1999) was the first who considered the interaction of aid and policy variables, which has become a commonly-used concept to evaluate aid effectiveness, which we have adopted in our empirical analysis. Svensson found a weak significant negative impact of aid on growth, but a positive and significant effect in democracies.

The most influential study on the relationship between aid and growth was carried out by Burnside and Dollar (2000). ${ }^{4}$ They analyzed the impact of foreign aid on growth considering the policy environment in aid-receiving countries. The main idea is that aid will be more effective if it is accompanied by a 'good policy'. They find that aid alone has no significant impact on growth, but has a positive effect in a 'good policy' environment. Thus, Burnside and Dollar conclude that aid is effective in developing countries "with good fiscal, monetary and trade policies" [Burnside and Dollar (2000), p. 847].

Numerous studies have been published since 2000 which reinvestigate the findings of Burnside and Dollar (2000) by extending or rearranging the data set, using alternative measures for 'good policy', and by using more sophisticated estimation procedures. Hansen and Tarp (2000), Hansen

\footnotetext{
3 For a comprehensive survey see McGillivray et al. (2006).

4 This article has been cited 227 times in journals of the social science citation index (January 2009).
} 
and Tarp (2001) and Dalgaard and Hansen (2001) find that aid has a significant positive impact on growth, but no evidence for a positive impact of 'good policy' on aid effectiveness. Moreover, they find evidence for diminishing returns to aid. Easterly (2003) and Easterly et al. (2004) criticize the results of Burnside and Dollar, showing that their results depend on the underlying measurement concept of 'good policy', the definition of aid, the periods considered, the adjustment for outliers, and the underlying data. Burnside and Dollar (2004a, 2004b) reply to these criticisms showing again that aid has a positive impact on growth in a 'good policy' environment. Their results are supported by Alvi et al. (2008), who applied a semiparametric estimation approach to a similar data set. Recent studies by Roodman (2007) and Rajan and Subramanian (2008) show, that this research question remains unanswered.

The literature published after this debate has begun to focus on issues other than 'good policy' that might impact aid effectiveness. Islam (2005), for example, focuses on political stability defined by assassinations, coups d'états, revolutions, riots, and strikes, showing that aid promotes growth only in a politically-stable environment. Further, Economides et al. (2008) investigates the relationship between aid, growth, and rent-seeking activities. They find a significant positive effect of aid on growth, which is mitigated by an endogenous increase in rent-seeking activities, triggered by the very same rise in aid.

Our empirical study continues from this point, and it sheds some more light on the conditions under which aid promotes growth. Our focus is on the federal structure of target countries, since aid might be more or less effective in decentralized countries. There is a limited number of studies investigating the relationship between decentralization and economic growth, but none have considered the interdependency with aid effectiveness. Davoodi and Zou (1998) and Woller and Phillips (1998) provided the first cross-country studies. While the former found a significant negative impact of decentralization on growth in developing countries, the latter found no significant relationship. These seemingly contradictory results are probably due to different measurement concepts for decentralization. More recently, Iimi (2005) studied a set of developed and developing countries, finding a positive impact of decentralization on growth, while Yilmaz (2000), Thießen (2003), and Thornton (2007) focused on highly developed countries, also finding a weak positive relationship or no significant effects. Enikolopov and Zhuravskaya (2007) analyze the impact of decentralization on growth in developing countries. They find that it depends on the institutional framework, that is the strength of national political parties and the degree of administrative subordination, whether the effect of decentralization is positive or negative. In the literature on decentralization and growth, there is a special focus on China and Chinese provinces. The first study of China by Zhang and Zou (1998) found a negative impact of decentralization on regional GDP growth, while Lin and Liu (2000) found a significant positive impact. Jin et al. (2005) analyzed the impact of local revenue autonomy on the development of the non-state sector and found a positive relationship. In all, the majority of studies found decentralization to have growthenhancing effects, although this finding is very sensitive to the underlying measurement concepts of decentralization and the particular country sample. 


\section{Empirical analysis}

The theoretical discussion of section 2 suggests that the degree of decentralization in aid-receiving countries may determine aid effectiveness. Following Oates' decentralization theorem aid should be more effective in decentralized countries and therefore stimulate more growth. At the same time, decentralization may have reverse effects, e.g., through increased corruption and cronyism, or poor bureaucratic quality at the local government level. In light of these opposing arguments, this section studies the relationship between aid and growth by considering the degree of decentralization in aid-receiving countries. Our empirical work attempts to answer two key questions: (1) Is the effect of aid on growth conditional on the federal structure of aid-receiving countries? (2) Do governments in donor countries and in international development agencies allocate aid effectively with respect to our findings in question (1)? After introducing the econometric model and the underlying data, we first test whether the 'good policy' hypothesis applies for our data set. Using these results as a benchmark, we estimate our model considering the interdependency between aid and decentralization. Finally, we test whether aid is allocated effectively in terms of our results, and we carry out several robustness checks.

\subsection{Econometric specification}

We parse our research questions by estimating variants of a time effects panel data model. Our basic growth regression for $N$ countries and $T$ time periods, where countries are indexed by $i$ and time by $t$, has the following form:

$$
\hat{y}_{i, t}=\alpha y_{i, t}+\sum_{j=1}^{k} \beta_{j} \operatorname{control}_{j, i, t}+\gamma_{1} \operatorname{aid}_{i, t}+\gamma_{2} \operatorname{dec}_{i, t}+\gamma_{3}\left(\operatorname{aid}_{i, t} \cdot \operatorname{dec}_{i, t}\right)+\mu_{t}+\epsilon_{i, t},
$$

Here $\hat{y}_{i, t}$ is real per capita GDP growth rate, $y_{i, t}$ is the logarithm of initial real per capita GDP, control $_{j, i, t}$ are $k$ exogenous control variables affecting growth, aid $_{i, t}$ is aid receipts relative to GDP, $d e c_{i, t}$ is the degree of fiscal or political decentralization, $\mu_{t}$ are time effects, and $\epsilon_{i, t}$ is a random error term.

The growth equation 1 is similar to specifications often used in the literature on aid effectiveness and the literature on growth in developing countries. The penultimate column of table A.6 in the appendix shows the main estimation equations of all empirical studies considered in our literature survey.

As is standard in this literature, we capture convergence effects by allowing growth during period $t$ to depend on $y_{i, t}$, the logarithm of real per capita GDP at the beginning of the period. Our growth equation also considers $k$ exogenous control variables, which we assume to be independent from aid and growth. These variables are necessary to capture institutional and political factors that might affect growth and also help us to avoid an omitted variable bias on our coefficients. One of these controls is ethnolinguistic fractionalization, which the literature has shown to be correlated with poor growth performance. Another control is the number of assassinations, which captures 
civil unrest, as well as an interaction term between ethnic fractionalization and assassinations. We also control for the institutional quality. Moreover, we consider inflation in our growth regressions, which serves as a proxy for macroeconomic stability. Our measures of ethnic fractionalization and institutional quality are time-invariant. Together with regional dummies for Sub-Saharan countries and East Asia, these controls capture time-invariant heterogeneities. In section 2, we argued that the effectiveness of foreign aid depends on decentralization, so our growth equation includes not only measures of aid and decentralization, but also their interactions.

After investigating the role of decentralization in the relationship between foreign aid and growth, we are interested to know if foreign aid is allocated correctly with respect to our findings. As mentioned above, developing agencies consider decentralization as a part of their poverty-reduction programs. Thus, it is straightforward to expect that decentralized countries receive more foreign assistance. Assuming that we find aid being more effective in centralized countries, the development strategy may have to be reconsidered. To examine the past allocation of aid, we estimate a time effects panel data model:

$$
\operatorname{aid}_{i, t}=\operatorname{\varphi aid}_{i, t-1}+\alpha y_{i, t}+\sum_{j=1}^{m} \beta_{j} \operatorname{control}_{j, i, t}+\delta_{1} \text { policy }_{i, t}+\delta_{2} \operatorname{dec}_{i, t}+\mu_{t}+\epsilon_{i, t},
$$

where control $_{j, i, t}$ are $m$ exogenous control variables that might affect aid receipts, and $p_{i, t}$ is a policy index similar to Burnside and Dollar (2000) [see section 4.3 for details].

Since decisions on aid payments by donor countries often influence aid flow to recipients over more than one period, we consider a lagged value of aid on the right hand side of the equation. Countries receiving a certain amount of aid in one period probably received a similar amount of aid in the following. Moreover, we control for the initial GDP at the beginning of each period, the population size, infant mortality, and regional dummies.

The equations are estimated using a panel across eight four-year periods from 1966 through 1997. Our data set consists of 60 developing countries. The bottleneck for our research is the availability of government finance data, which is required to calculate decentralization measures. This restricts our sample to 60 countries. Before we test the impact of fiscal decentralization on aid effectiveness, we first test the 'good policy' hypothesis for our sample, and then use these results as benchmark. The number of periods and countries in our sample implies a maximum of 480 observations. Since we have only 366 observations in our regressions, our panel is unbalanced.

\subsection{The Data}

The GDP and aid data are from Worldbank (2006); the number of assassinations, the budget surplus, and the institutional quality index come from the Easterly et al. (2004) data set. Alesina et al. (2003) provide the data for ethnolinguistic fractionalization; the data on economic openness, inflation, population size, and infant mortality are from Worldbank (2006). ${ }^{5}$

5 See Table A.1 in the appendix for details. Table A.2 provides summary statistics of all considered variables. 
The main variables of interest are our measures of development, foreign aid, and decentralization. In line with the literature, we use the real GDP per capita growth rate as measure of economic development. As measures for foreign assistance, two variables have often been used: official development assistance (ODA) and effective development assistance (EDA), each as share of GDP. The main difference between EDA and ODA is that EDA is the sum of grants and the grant equivalents of official loans, whereas ODA includes both the direct grants and concessional loans for which the grant component is above $25 \%$. Which measure to use, and whether it should be used in current or constant U.S. dollars, is widely discussed in the literature [see, e.g., Chang et al. (1998)]. In the end, it should not make any difference in our context since Dalgaard and Hansen (2001) have shown that the Pearson correlation between nominal ODA/GDP and nominal $\mathrm{EDA} / \mathrm{GDP}$ is 0.98 , and the correlation between nominal ODA/GDP and real EDA/GDP is 0.95 [see also Roodman (2007)]. We decided to use the nominal ODA/GDP ratio, providing us with one additional four-year period in our panel.

The last variable to be discussed in detail is our decentralization index. Several measurement concepts are used in the literature [see, e.g., Treisman (2002) and Rodden (2004)]. Decentralization is often viewed as the devolution of authority towards sub-national governments, with total government authority over society and economy perceived as fixed. Attempts to define and measure decentralization have focused on fiscal authority (rather than political authority). In our context, we are interested in both issues: Is aid spent on the central or local level? Do central or local governments decide on aid assignment to particular projects? The first issue can be approximated by using the degree of expenditure decentralization, which relates expenditures of sub-national governments (state + local) to total government expenditures. The IMF Government Finance Statistics provides the underlying data. The degree of expenditure decentralization has often been used in the literature, particularly the literature on growth and decentralization, discussed in section 3 .

However, the degree of expenditure decentralization is unable to reflect the political dimension of the decision-making process. For this purpose, we refer to decentralization measures provided by Treisman (2002) and Fan et al. (2009). Since it is very difficult to create measures for political processes, Treisman has created several dummy variables based on the constitutions of countries. A sub-national legislature is said to have 'residual authority' if the constitution assigns the exclusive right to legislate on issues that are not specifically assigned to one level of government. Another measure captures the 'autonomy' of a sub-national legislature regarding a given question, and whether the constitution reserves exclusive decision-making power on that question. From these two dummy variables, Treisman creates a third variable which captures whether sub-national governments have 'residual authority and/or autonomy'. We use all three dummy variables to test the impact of political decentralization on the aid-growth nexus. ${ }^{6}$

\footnotetext{
${ }_{6}$ Our measures of fiscal and political decentralization indeed reflect different kinds of decentralization, as the correlation coefficients show ( $t$-values in parenthesis): expenditure decentralization - residual authority: 0.17 (3.93); expenditure decentralization - autonomy: 0.16 (3.66), expenditure decentralization - residual authority and/or autonomy: 0.03 (0.81); residual authority - autonomy: 0.67 (21.08); residual authority - residual authority and/or autonomy: 0.76 (27.15); autonomy - residual authority and/or autonomy: 0.90 (48.28).
} 


\subsection{Benchmark Regressions: The 'Good Policy' Hypothesis}

Since our data set differs slightly from those of other authors, we first investigate whether the 'good policy' hypothesis also holds for our sample, then using these results as a benchmark. The 'good policy' index policy $_{i, t}$ is constructed from an OLS growth regression with no aid terms [compare Burnside and Dollar (2000) or Easterly et al. (2004)]:

$$
\hat{y}_{i, t}=\alpha y_{i, t}+\sum_{j=1}^{k} \beta_{j} \operatorname{control}_{j, i, t}+\lambda_{1} \text { budget }_{i, t}+\lambda_{2}\left(1+\text { inf }_{i, t}\right)+\lambda_{3} \text { open }_{i, t}+\mu_{t}+\epsilon_{i, t},
$$

where budget $_{i, t}$ is the budget surplus, inf $f_{i, t}$ is the inflation rate, and open ${ }_{i, t}$ reflects economic openness measured by the ratio between total trade (exports + imports) and GDP. Table A.3 in the appendix provides the estimation results. The policy index is formed by using the regression coefficients:

$$
\text { policy }=0.064+0.225 \cdot \text { budget }-0.066 \cdot \log (1+\text { inf })-0.0003 \cdot \text { open } .
$$

In this way we let the growth regression determine the relative importance of the different policies in our index. The advantage of this procedure is that we capture those macroeconomic country characteristics in just one variable, which we can later use to analyze aid effectiveness. Unfortunately, this approach is problematic, since we are dealing with a generated regressor [Wooldridge (2002)]. We dismiss these problems for a better comparability of our benchmark results.

This policy index is now used in a growth regression to investigate whether aid's impact on growth depends on those 'good policies' $\left(\right.$ policy $\left._{i, t}\right)$. The basic estimation equation looks similar to equation (1), discussed above:

$$
\hat{y}_{i, t}=\alpha y_{i, t}+\sum_{j=1}^{k} \beta_{j} \operatorname{control}_{j, i, t}+\rho_{1} \operatorname{aid}_{i, t}+\rho_{2} \text { policy }_{i, t}+\rho_{3}\left(\operatorname{aid}_{i, t} \cdot \text { policy }_{i, t}\right)+\mu_{t}+\epsilon_{i, t} .
$$

In addition to the control variables, our regressions include foreign aid $\left(a_{i,} d_{i, t}\right)$, the policy index $\left(\right.$ policy $\left._{i, t}\right)$, and the interaction of aid and the policy index $\left(\right.$ aid $_{i, t} \cdot$ policy $\left._{i, t}\right)$. Since we use an interaction term of two continuous variables, the coefficients of our variables have to be interpreted with caution. Without interaction of variables, each coefficient reflects the marginal impact of the corresponding independent variable on the dependent variable. With the interaction of variables, the coefficient $\rho_{1}\left(\rho_{2}\right)$ only captures the effect of aid (policy) on growth when policy (aid) is zero. Now the marginal impact of aid on growth depends on the sign and magnitude of the coefficient of aid $\left(\rho_{1}\right)$, and the sign and magnitude of the coefficient of our interaction variable $\left(\rho_{3}\right){ }^{7}$ Due to possible heteroscedasticity and serial correlation, we calculate panel corrected standard errors

(PCSE) following Beck and Katz (1995). Table 2 presents OLS estimation results for alternative specifications of growth equation (5).

\footnotetext{
7 For a detailed explanation, see section 4.4 .
} 
Table 2: Benchmark results

\begin{tabular}{|c|c|c|c|}
\hline & \multicolumn{3}{|c|}{ Dependent variable: real GDP growth } \\
\hline & (1) & (2) & (3) \\
\hline initial GDP & 0.002 & 0.001 & -0.003 \\
\hline & $(0.11)$ & $(0.06)$ & $(-0.17)$ \\
\hline ethnic fractionalization & $\begin{array}{l}-0.053^{*} \\
(-1.85)\end{array}$ & $\begin{array}{l}-0.053^{*} \\
(-1.84)\end{array}$ & $\begin{array}{l}-0.055^{*} \\
(-1.90)\end{array}$ \\
\hline assassinations & $\begin{array}{l}-0.027^{* * *} \\
(-2.96)\end{array}$ & $\begin{array}{l}-0.027^{* * *} \\
(-2.95)\end{array}$ & $\begin{array}{l}-0.026^{* * *} \\
(-2.73)\end{array}$ \\
\hline ethnic $\times$ assassinations & $\begin{array}{l}0.047^{* *} \\
(2.43)\end{array}$ & $\begin{array}{l}0.047^{* *} \\
(2.41)\end{array}$ & $\begin{array}{l}0.043^{* *} \\
(2.16)\end{array}$ \\
\hline institutional quality & $\begin{array}{l}0.009^{* *} \\
(2.36)\end{array}$ & $\begin{array}{l}0.009^{* *} \\
(2.35)\end{array}$ & $\begin{array}{l}0.009^{* *} \\
(2.33)\end{array}$ \\
\hline Sub-Saharan Africa & $\begin{array}{l}-0.026 \\
(-1.14)\end{array}$ & $\begin{array}{l}-0.025 \\
(-1.13)\end{array}$ & $\begin{array}{l}-0.025 \\
(-1.13)\end{array}$ \\
\hline East-Asia & $\begin{array}{l}0.120^{* * *} \\
(10.25)\end{array}$ & $\begin{array}{l}0.119^{* * *} \\
(10.11)\end{array}$ & $\begin{array}{l}0.114^{* * *} \\
(9.36)\end{array}$ \\
\hline policy index & $\begin{array}{l}0.997^{* * * *} \\
(5.34)\end{array}$ & $\begin{array}{l}1.038^{* * *} \\
(5.67)\end{array}$ & $\begin{array}{l}1.146^{* * *} \\
(3.84)\end{array}$ \\
\hline aid & $\begin{array}{l}-0.018 \\
(-0.11)\end{array}$ & $\begin{array}{l}-0.027 \\
(-0.17)\end{array}$ & $\begin{array}{l}-0.229 \\
(-0.49)\end{array}$ \\
\hline$(\text { aid })^{2}$ & & & $\begin{array}{r}0,966 \\
(0.60)\end{array}$ \\
\hline aid $\times$ policy index & & $\begin{array}{r}-0.637 \\
(-0.31)\end{array}$ & $\begin{array}{r}-4.56 \\
(-0.55)\end{array}$ \\
\hline$(\text { aid })^{2} \times$ policy index & & & $\begin{array}{l}13.64 \\
(0.64)\end{array}$ \\
\hline period dummies & yes & yes & yes \\
\hline obs. & $334(60)$ & $334(60)$ & $334(60)$ \\
\hline adj.- $R^{2}$ & 0.33 & 0.32 & 0.32 \\
\hline
\end{tabular}

In Table 2 column (1) we present estimation results without the interaction of aid and the policy index; in column (2) we added the interaction term; and in column (3) we added an interaction term of aid squared and policy to investigate whether diminishing or increasing returns to aid exists.

Interestingly, we were unable to identify any significant relationship between aid and growth for our sample of countries. The policy index has the expected significant positive effect on growth in the first specification. The 'good policy' hypothesis would now require a significant marginal effect of aid on growth conditional on the policy index. Although the interaction term in specification 2 and 3 is insignificant, this does not necessarily mean that no such relationship exists. For this purpose, we have to calculate the marginal effects, which are indeed insignificant for all relevant values of the policy variable. We therefore conclude that the 'good policy' hypothesis does not hold for our sample of countries, which is in line with Dalgaard and Hansen (2001), Easterly (2003), Easterly et al. (2004) among others.

Let us now turn to the interpretation of our control variables. The initial per capita GDP as control for the convergence hypothesis is insignificant at conventional confidence levels, consistent with most studies on aid and growth [see, e.g., Burnside and Dollar (2000), Dalgaard and Hansen (2001), and Easterly et al. (2004)]. Countries with a high degree of ethnolinguistic fractionalization face slower growth rates, if there are no riots and/or wars (assassinations $=0$ ). In the case of 
assassinations, we have to calculate the marginal effects on growth again [see figure 3 in the appendix]. It turns out that assassinations have a significant negative effect on growth in countries with a low degree of ethnolinguistic fractionalization. Our variable for institutional quality has a significant positive impact on growth; the Sub-Saharan Africa dummy is insignificant, while the East Asia dummy is positive and highly significant. Due to space limitations, we do not report the period dummies. Our regressions explain about $32 \%$ of the variance of the dependent variable, which is consistent with the results of existing studies.

\subsection{Main Estimation Results: Aid, Growth and Devolution}

In this section, we test our main hypothesis that the relationship between foreign aid and growth is conditional on the degree of decentralization. Our discussion of the relevant theoretical literature in section 2 has shown that both fiscal and political decentralization may play a role in the aidgrowth nexus. To investigate this research question, we estimate variants of our empirical growth equation (1). First, we turn to test the impact of fiscal decentralization, as reflected by the degree of expenditure decentralization, on the aid-growth relationship; second, we focus on measures of political decentralization.

\section{Fiscal Decentralization}

Our measure of fiscal decentralization is the commonly-used degree of expenditure decentralization, which relates expenditures at the state and local government level to total government expenditures. The IMF Government Finance Statistics (GFS) includes budgetary data on 60 aid-receiving countries. The problem of the IMF data is that it does not cover our whole observation period, which starts in 1966. The first entries in the GFS are for 1970, and there are several missing values. Therefore, we build the average of decentralization measures between the years 1970 and 1997. We lose the time series properties of the decentralization data, but we are able to substantially extend the number of observations in our estimations. At the end of this section, we provide a robustness test on this issue.

To address whether the effectiveness of aid depends on the degree of decentralization, we include two interactive terms - aid $\times$ expenditure decentralization and (aid) $)^{2} \times$ expenditure decentralization - into our regression. Table 3 presents our main results. In column (1) we show OLS estimations without interaction of aid and the degree of expenditure decentralization; in column (2) we added the interaction term; and in column (3) we added an interaction term of aid squared and the degree of expenditure decentralization. In the following three columns, we repeat these estimations by applying the two-stage-least-squares (TSLS) estimation procedure instrumented for foreign aid by its one-period (four-year averaged) lagged values, as donor countries might respond to negative growth shocks by providing more assistance. In this case, aid is influenced by growth, and we would have an endogeneity bias. 
Table 3: Main Results, Fiscal Decentralization

\begin{tabular}{|c|c|c|c|c|c|c|}
\hline & \multicolumn{6}{|c|}{ Dependent variable: real GDP growth } \\
\hline & & OLS & & & TSLS & \\
\hline & (1) & $(2)$ & (3) & $(4)$ & (5) & (6) \\
\hline \multirow[t]{2}{*}{ initial GDP } & -0.002 & 0.001 & -0.000 & 0.011 & 0.013 & -0.020 \\
\hline & $(-0.13)$ & $(0.07)$ & $(-0.02)$ & $(0.68)$ & $(0.86)$ & $(-0.45)$ \\
\hline \multirow[t]{2}{*}{ ethnic fractionalization } & $-0.067 * *$ & $-0.061 * *$ & $-0.064^{* *}$ & $-0.071 * *$ & $-0.066^{* *}$ & $-0.109^{* *}$ \\
\hline & $(-2.26)$ & $(-2.17)$ & $(-2.21)$ & $(-2.33)$ & $(-2.22)$ & $(-2.05)$ \\
\hline assassinations & $\begin{array}{l}-0.027^{* * *} \\
(-2.83)\end{array}$ & $\begin{array}{l}-0.030^{* * *} \\
(-3.28)\end{array}$ & $-0.030 * * *$ & $\begin{array}{l}-0.032^{* * *} \\
(-3.45)\end{array}$ & $-0.035^{* * *}$ & $\begin{array}{l}-0.023 \\
(-1.38)\end{array}$ \\
\hline \multirow[t]{2}{*}{ ethnic $\times$ assassinations } & $0.046^{* *}$ & $0.047^{* *}$ & $0.046^{* *}$ & $0.056^{* * *}$ & $0.057^{* * *}$ & 0.034 \\
\hline & $(2.28)$ & $(2.42)$ & $(2.31)$ & $(2.79)$ & $(2.85)$ & $(1.02)$ \\
\hline \multirow[t]{2}{*}{ institutional quality } & 0.005 & 0.002 & 0.003 & 0.005 & 0.002 & 0.010 \\
\hline & $(1.37)$ & $(0.53)$ & $(0.68)$ & $(1.17)$ & $(0.50)$ & $(1.06)$ \\
\hline $\log (1+$ inflation $)$ & $\begin{array}{l}-0.073^{* * *} \\
(-5.75)\end{array}$ & $\begin{array}{l}-0.078^{* * *} \\
(-5.83)\end{array}$ & $\begin{array}{l}-0.077^{* * *} \\
(-5.87)\end{array}$ & $\begin{array}{l}-0.069 * * * \\
(-5.46)\end{array}$ & $\begin{array}{l}-0.075^{* * *} \\
(-5.41)\end{array}$ & $\begin{array}{l}-0.076^{* * *} \\
(-4.90)\end{array}$ \\
\hline \multirow[t]{2}{*}{ Sub-Saharan Africa } & -0.012 & -0.006 & -0.007 & -0.018 & -0.012 & -0.026 \\
\hline & $(-0.59)$ & $(-0.34)$ & $(-0.39)$ & $(-0.86)$ & $(-0.59)$ & $(-1.10)$ \\
\hline \multirow[t]{2}{*}{ East-Asia } & $0.115^{* * *}$ & $0.112^{* * *}$ & $0.112^{* * *}$ & $0.120 * * *$ & $0.118^{* * *}$ & $0.093^{* * *}$ \\
\hline & $(9.36)$ & (10.73) & (10.18) & $(9.38)$ & $(10.13)$ & $(2.84)$ \\
\hline \multirow[t]{2}{*}{ expenditure decentralization } & $0.001 *$ & $0.002 * * *$ & $0.002^{* * *}$ & $0.001 * *$ & $0.002 * * *$ & -0.001 \\
\hline & $(1.90)$ & $(5.08)$ & $(3.96)$ & $(2.36)$ & $(4.84)$ & $(-0.26)$ \\
\hline \multirow[t]{2}{*}{ aid } & -0.180 & 0.178 & 0.037 & 0.093 & 0.377 & -2.60 \\
\hline & $(-1.16)$ & $(1.04)$ & $(0.08)$ & $(0.41)$ & $(1.51)$ & $(-0.80)$ \\
\hline \multirow[t]{2}{*}{$(\text { aid })^{2}$} & & & 0.748 & & & 14.15 \\
\hline & & & $(0.54)$ & & & $(0.98)$ \\
\hline \multirow[t]{2}{*}{ aid $\times$ decentralization } & & $-0.035^{* * *}$ & -0.021 & & $-0.031 * * *$ & 0.174 \\
\hline & & $(-6.40)$ & $(-1.00)$ & & $(-3.94)$ & $(0.90)$ \\
\hline \multirow[t]{2}{*}{$(\text { aid })^{2} \times$ decentralization } & & & -0.096 & & & -1.313 \\
\hline & & & $(-0.72)$ & & & $(-1.07)$ \\
\hline period dummies & yes & yes & yes & yes & yes & yes \\
\hline obs. & $366(60)$ & $366(60)$ & $366(60)$ & $354(60)$ & $354(60)$ & $354(60)$ \\
\hline $\operatorname{adj} .-R^{2}$ & 0.32 & 0.35 & 0.35 & 0.30 & 0.34 & 0.15 \\
\hline
\end{tabular}

The estimation without the interaction of aid and decentralization shows that the degree of expenditure decentralization is positively associated with economic growth for our sample of developing countries, which is consistent with earlier findings in the literature on decentralization and growth [see section 3]. Importantly, foreign aid has no significant growth effects. Since we are primarily interested in the impact of fiscal decentralization on aid effectiveness, we focus on the specification using the interaction term. Column (2) shows that the coefficient of our decentralization measure is significant positive, the coefficient of aid is insignificant, and the coefficient of the interaction term is significant negative. However, we are not particularly interested in the individual statistical significance of either of these terms. Instead, we want to know their joint significance or, more correctly, the marginal effect of aid on growth. ${ }^{8}$ The marginal effect can be calculated using $\gamma_{1}$ and $\gamma_{3}$ given the degree of decentralization [see also equation 1]:

$$
\frac{\partial \hat{y}}{\partial a i d}=\gamma_{1}+\gamma_{3} \cdot d e c
$$

Our interaction model asserts that the effect of a change in aid on growth depends on the value of the conditioning variable decentralization. While it is possible to calculate the marginal effect

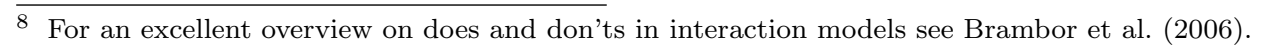


using equation 6 and the results obtained in Table 3 , it is not possible to do the same for the standard errors. The standard error of interest is:

$$
\hat{\sigma}_{\frac{\partial \hat{y}}{\partial a i d}}=\sqrt{\operatorname{var}\left(\gamma_{1}\right)+\operatorname{dec}^{2} \cdot \operatorname{var}\left(\gamma_{3}\right)+2 \cdot \operatorname{dec} \cdot \operatorname{cov}\left(\gamma_{1} \gamma_{3}\right)}
$$

The standard errors are used to calculate the confidence band around the marginal effects. To help the reader see more precisely how the marginal effect of aid on growth varies by the degree of decentralization in developing countries, this marginal effect is plotted in Figure 1. The figure also includes confidence bands for 1 and 10 percent significance levels. The cutoff value of decentralization is the value of decentralization for which $\partial($ growth $) / \partial($ aid $)=0$ is 5.08 in the fully specified regression [column (2)]. This implies that - at best - for only a quarter of the countries in the sample, increased aid is associated with higher growth. For countries close to the cutoff value, the effect of aid on growth is small, while the negative growth impact of aid for the most decentralized countries in the sample is fairly high. The marginal effect is statistically different from zero, with more than 90 percent (99 percent) confidence with a degree of expenditure decentralization exceeding roughly 12 percent (17 percent). In other words, the impact of aid on growth is significantly negative for nearly 40 percent of countries in our sample. Our results imply that foreign aid is less effective in decentralized countries.

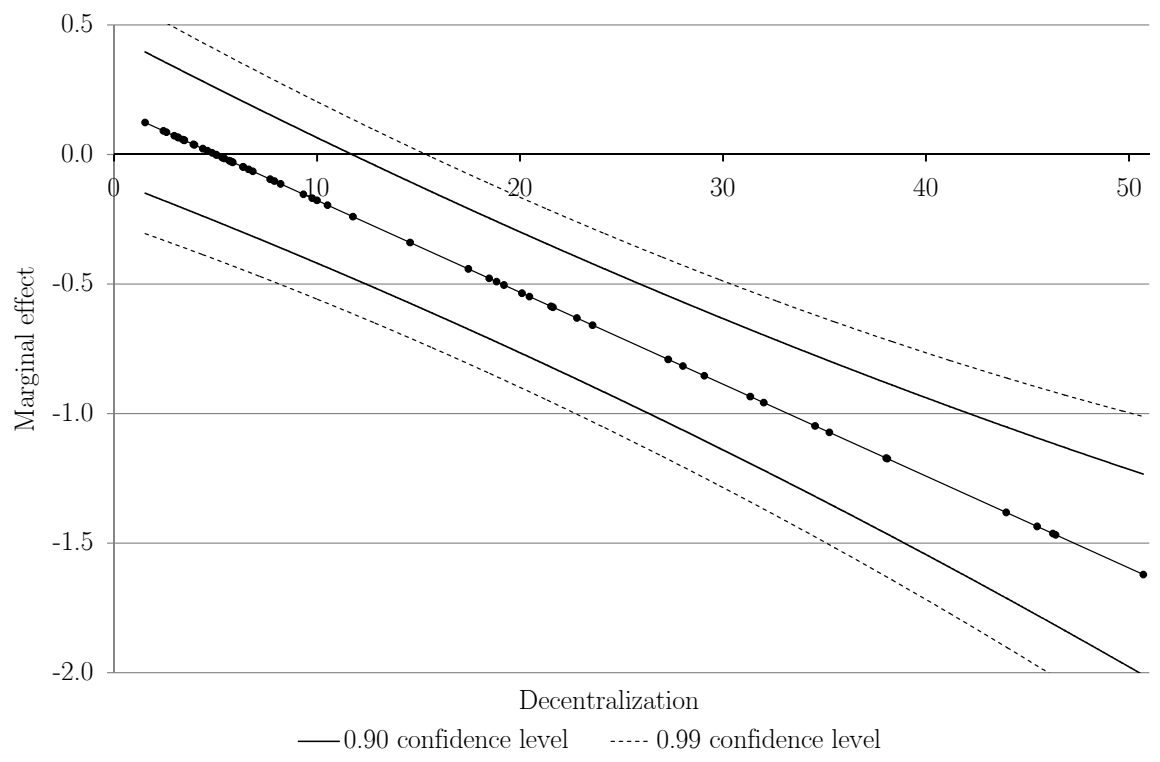

Figure 1: Marginal effect of aid on growth: fiscal decentralization

The results of Table 3 columns (4)-(6) show that our results remain widely unchanged when we apply the TSLS estimation procedure. In particular, the coefficients of the degree of expenditure decentralization, the aid ratio, and the interaction term are similar in magnitude and significance 
across the OLS and TSLS regressions. The cutoff-value for which the marginal impact of aid on growth becomes zero is 12.2. The effects of all other variables are unaffected by using TSLS.

\section{Political Decentralization}

As discussed above, the degree of expenditure decentralization is unable to reflect the political dimension of the devolution of powers. Nevertheless, it is interesting to identify the level of government on which decisions regarding aid appropriation are made. For this purpose, we use the decentralization measures residual authority, autonomy, and residual authority and/or autonomy developed by Treisman (2002). We admit that this is just an approximation for what we really desire to measure in this context. In fact, there exists no reliable cross-country information on the process of appropriation decisions on aid in all considered aid-receiving countries. What we have tested here is whether aid is more or less effective in countries with sub-national government authorities and autonomy, respectively.

The results of OLS estimations of equation (1) considering measures of political decentralization are presented in Table 4. Since Treisman's decentralization measures are only available for a smaller number of countries than our measure of fiscal decentralization, we lose 14 countries and 100 observations in our data set. However, the bias in observations is only a minor problem, since estimations using the degree of expenditure decentralization based on the same smaller sample return similar results to those of Table $3 .{ }^{9}$

9 OLS estimations return the following coefficients: expenditure decentralization 0.003 ( $t$-value: 5.11 ); aid 0.177 (0.73); aid $\times$ expenditure decentralization -0.038 (-5.92). The sample consists of 47 countries with 265 observations, $\bar{R}^{2}=0.37$. The results are available from the authors upon request. 
Table 4: Main Results, Political Decentralization

\begin{tabular}{|c|c|c|c|c|c|c|}
\hline & \multicolumn{6}{|c|}{ Dependent variable: real GDP growth } \\
\hline & (1) & (2) & (3) & (4) & (5) & (6) \\
\hline initial GDP & -0.021 & $-0.032 * *$ & $-0.023 *$ & $-0.048^{* * *}$ & -0.021 & $-0.040 * * *$ \\
\hline & $(-1.43)$ & $(-2.15)$ & $(-1.66)$ & $(-3.25)$ & $(-1.05)$ & $(-2.15)$ \\
\hline ethnic fractionalization & -0.041 & -0.032 & -0.044 & -0.039 & -0.045 & -0.040 \\
\hline & $(-1.19)$ & $(-0.96)$ & $(-1.31)$ & $(-1.19)$ & $(-1.41)$ & $(-1.34)$ \\
\hline assassinations & -0.007 & -0.004 & 0.002 & 0.005 & -0.006 & -0.005 \\
\hline & $(-0.41)$ & $(-0.23)$ & $(0.12)$ & $(0.26)$ & $(-0.37)$ & $(-0.30)$ \\
\hline ethnic $\times$ assassinations & 0.000 & -0.014 & -0.034 & -0.047 & -0.001 & -0.001 \\
\hline & $(0.00)$ & $(-0.39)$ & $(-0.79)$ & $(-1.10)$ & $(-0.04)$ & $(-0.35)$ \\
\hline institutional quality & 0.002 & 0.001 & 0.001 & 0.002 & 0.001 & 0.001 \\
\hline & $(0.36)$ & $(0.29)$ & $(0.18)$ & $(0.47)$ & $(0.29)$ & $(0.29)$ \\
\hline $\log (1+$ inflation $)$ & $-0.064 * * *$ & $-0.064 * * *$ & $-0.059 * * *$ & $-0.064 * * *$ & $-0.062 * * *$ & $-0.066 * * *$ \\
\hline & $(-4.52)$ & $(-4.63)$ & $(-4.15) *$ & $(-4.61) *$ & $(-4.09) *$ & $(-4.17)$ \\
\hline Sub-Saharan Africa & $\begin{array}{l}-0.044 * \\
(-1.96)\end{array}$ & $\begin{array}{l}-0.037 * \\
(-1.69)\end{array}$ & $\begin{array}{l}-0.041 * \\
(-1.80)\end{array}$ & $\begin{array}{l}-0.042 * \\
(-1.90)\end{array}$ & $\begin{array}{l}-0.040 * \\
(-1.69)\end{array}$ & $\begin{array}{l}-0.035 \\
(-1.60)\end{array}$ \\
\hline East-Asia & $\begin{array}{l}0.109 * * * \\
(5.44)\end{array}$ & $\begin{array}{l}0.096^{* * *} \\
(4.81)\end{array}$ & $\begin{array}{l}0.109 \text { *** } \\
(5.40)\end{array}$ & $\begin{array}{l}0.090 \text { *** } \\
(4.49)\end{array}$ & $\begin{array}{l}0.111 \text { *** } \\
(7.16)\end{array}$ & $\begin{array}{l}0.097 \text { *** } \\
(6.80)\end{array}$ \\
\hline aid & $\begin{array}{l}-0.390 * * \\
(-2.54)\end{array}$ & $\begin{array}{l}-1.917 * * * \\
(-4.76)\end{array}$ & $\begin{array}{l}-0.401 * * \\
(-2.58)\end{array}$ & $\begin{array}{l}-2.033 * * * \\
(-4.93)\end{array}$ & $\begin{array}{l}-0.390 * \\
(-1.83)\end{array}$ & $\begin{array}{l}-1.90 * * * \\
(-4.55)\end{array}$ \\
\hline$(\text { aid })^{2}$ & & $\begin{array}{l}6.554^{* * *} \\
(4.12)\end{array}$ & & $\begin{array}{l}6.728^{* * *} \\
(4.17)\end{array}$ & & $\begin{array}{l}6.367^{* * *} \\
(3.62)\end{array}$ \\
\hline residual power & $\begin{array}{r}0.003 \\
(0.13)\end{array}$ & $\begin{array}{l}-0.018 \\
(-0.78)\end{array}$ & & & & \\
\hline aid $\times$ residual power & $\begin{array}{l}-0.118 \\
(-0.21)\end{array}$ & $\begin{array}{r}1.239 \\
(0.78)\end{array}$ & & & & \\
\hline$(\text { aid })^{2} \times$ residual power & & $\begin{array}{l}-8.664 \\
(-0.69)\end{array}$ & & & & \\
\hline autonomy & & & $\begin{array}{l}-0.003 \\
(-0.16)\end{array}$ & $\begin{array}{r}-0.007 \\
(0.30)\end{array}$ & & \\
\hline aid $\times$ autonomy & & & $\begin{array}{r}-0.374 \\
(-0.66)\end{array}$ & $\begin{array}{l}-3.454 \\
(-1.54)\end{array}$ & & \\
\hline$(\text { aid })^{2} \times$ autonomy & & & & $\begin{array}{r}26.64 \\
(1.55)\end{array}$ & & \\
\hline residual power + autonomy & & & & & $\begin{array}{l}-0.004 \\
(-0.20)\end{array}$ & $\begin{array}{l}-0.005 \\
(-0.19)\end{array}$ \\
\hline aid $\times$ (residual power + autonomy $)$ & & & & & $\begin{array}{l}-0.376 \\
(-0.96)\end{array}$ & $\begin{array}{l}-2.852 * \\
(-1.89)\end{array}$ \\
\hline$(\text { aid })^{2} \times($ residual power + autonomy $)$ & & & & & & $\begin{array}{l}21.67^{* *} \\
(2.09)\end{array}$ \\
\hline period dummies & yes & yes & yes & yes & yes & yes \\
\hline obs & $263(46)$ & $263(46)$ & $257(46)$ & $257(46)$ & $265(47)$ & $265(47)$ \\
\hline adj.- $R^{2}$ & 0.30 & 0.35 & 0.31 & 0.36 & 0.31 & 0.35 \\
\hline
\end{tabular}

Table 4 reports six different specifications of our growth equation. The estimation reported in column (1) considers aid, the residual power dummy, and the interactions of aid and residual power. Column (2) considers an additional interaction term of (aid) ${ }^{2}$ and residual power. Similar specifications are used in the following columns considering the decentralization measures autonomy and residual power + autonomy, respectively. As in the case of our regressions with the degree of expenditure decentralization, we refer to the marginal effects of aid on growth. Figure 2 shows the results considering residual power and/or autonomy as measure for political decentralization. Again, the marginal effects of aid on growth are negative in centralized and decentralized countries alike. The negative effect increases with the degree of political decentralization, which is similar to the results for fiscal decentralization. However, the effect is only significant in cases of more centralized countries. In all, political decentralization has the similar adverse effect on the effectiveness 


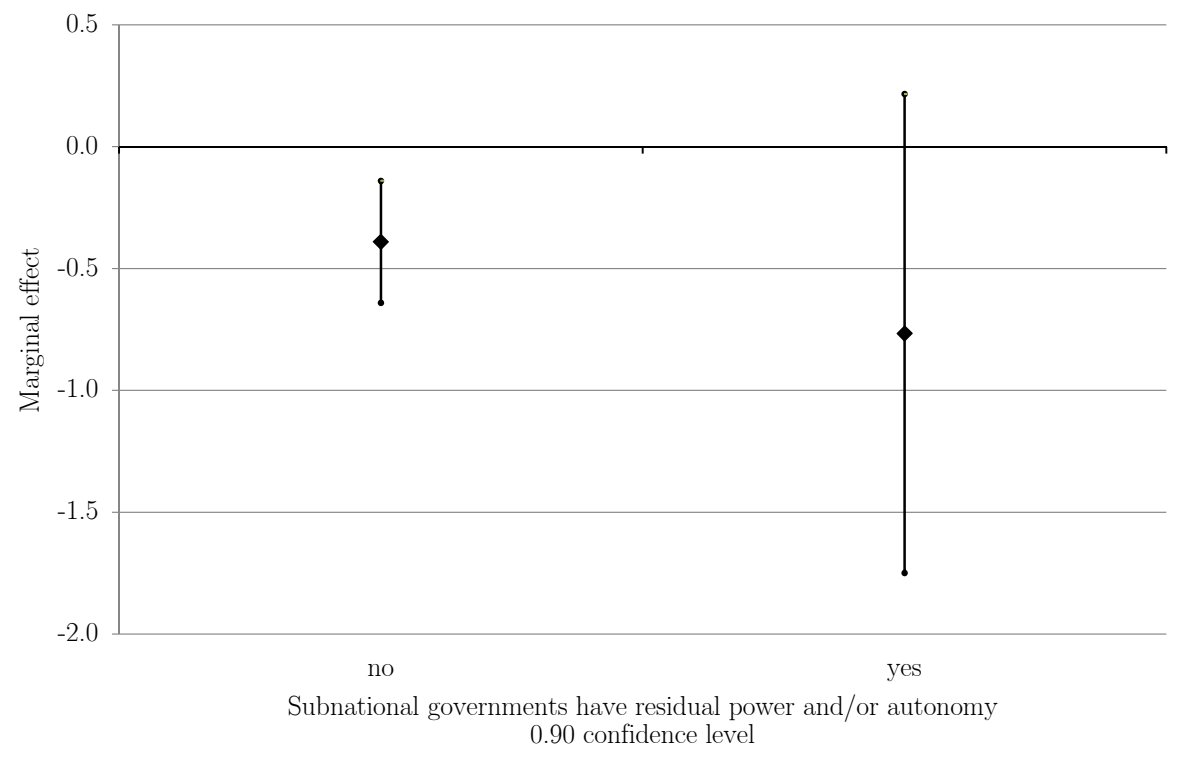

Figure 2: Marginal effect of aid on growth: political decentralization

of foreign aid as fiscal decentralization.

\section{Sensitivity Analysis and Robustness Checks}

The first robustness test is to check whether our results are sensitive to single outliers. For this purpose, we adopt the Hadi (1994) method for identifying and eliminating outliers. The Hadi method measures the distance of data points from the main body of data, and then iteratively reduces the sample to exclude distant data points. This procedure identifies twelve outliers we remove from our sample. ${ }^{10}$ We re-estimate our empirical growth model obtaining similar results to those presented above. ${ }^{11}$ In another sample adjustment, we exclude former communist Warsaw Pact countries, since one might argue that these countries are not comparable to South American or African countries. This does not change anything in our results.

An important test is to use a time-variant decentralization measure. In our main regressions we have built a long period average (1970-1997) of the degree of expenditure decentralization, since we have only a few observations for some countries in our data set. Now we use the original frequency of the IMF government finance data and re-estimate our empirical model. In doing so, we lose 3 of our 60 countries, and our total number of observations declines from 366 to 188. Nevertheless, our results are insensitive to these robustness tests, as shown in Table A.4 in the appendix. We have also checked for the robustness of our results if we use the same sample for our measure of fiscal decentralization as in the regressions considering political decentralization. Again, our results remain robust.

\footnotetext{
10 The outliers are Albania 1990-1993, Botswana 1974-1977, Congo 1994-1997, Gambia 1986-1989, Jordan 1978-1981, Senegal 1978-1997, Mongolia 1990-1997, and Zambia 1994-1997.

11 The results are available from the authors upon request.
} 
A further robustness check is to combine the "good policy" hypothesis and our hypothesis that decentralization determines aid effectiveness. For this purpose, we include both the policy index and the degree of expenditure decentralization, as well as their interactions with aid and (aid) $)^{2}$ in our growth equation. Table A.5 in the appendix presents the main results for the coefficients of interest, confirming our main findings.

\subsection{Aid Allocation}

The estimations of our empirical growth model show that aid is less effective - or even harmful in decentralized countries. In light of this finding, it is interesting to study whether aid is allocated effectively. For this purpose, we investigate the determinants of the amount of aid received by developing countries by estimating equation (2).

Since decisions on the amount of aid spent in a particular country are made for a longer period of time, we consider a dynamic panel model including a lagged dependent variable on the right hand side of the equation. The level of aid received in one period probably depends on the level of aid that was received earlier. ${ }^{12}$ Moreover, we include the initial GDP per capita as a control variable since we expect less foreign aid in richer countries. Earlier studies, e.g., Burnside and Dollar (2000) have shown that the population size is a determinant of aid flow, so we include the $\log$ of population. Since aid might also react to the distress of the poorest people in developing countries, we consider infant mortality as a control. Furthermore, we add a Sub-Saharan dummy, a dummy for Central America, and a dummy for those countries that are former French colonies, in order to capture donors' strategic interests. The most important variables are the policy index and our different measures of fiscal and political decentralization. The results are presented in Table 5 .

Our regressions show that the amount of aid received by a particular country depends positively on the level of aid spent during the previous period, which is in line with our predictions. Moreover, richer and larger countries receive less foreign aid. The distress of poor people reflected by infant mortality has no significant effect on aid. This is in line with the findings of Boone (1996). The policy index has a significant negative effect, indicating that countries with "good" macroeconomic policies receive less aid. This may be due to the fact that donors react to the good performance of countries with a cut in development assistance. Most importantly, all of our decentralization measures have a significant positive impact on aid, meaning that more aid is spent in decentralized countries. This is, however, not efficient in light of our findings from the growth regressions, which revealed that decentralization has a negative impact on aid effectiveness.

\footnotetext{
12 We are aware of the potential problems estimating dynamic panels with OLS, but since we do not include country fixed effects and since we are interested just in the sign of the coefficient of our decentralization variable, we avoid applying more sophisticated estimation procedures.
} 
Table 5: Aid allocation

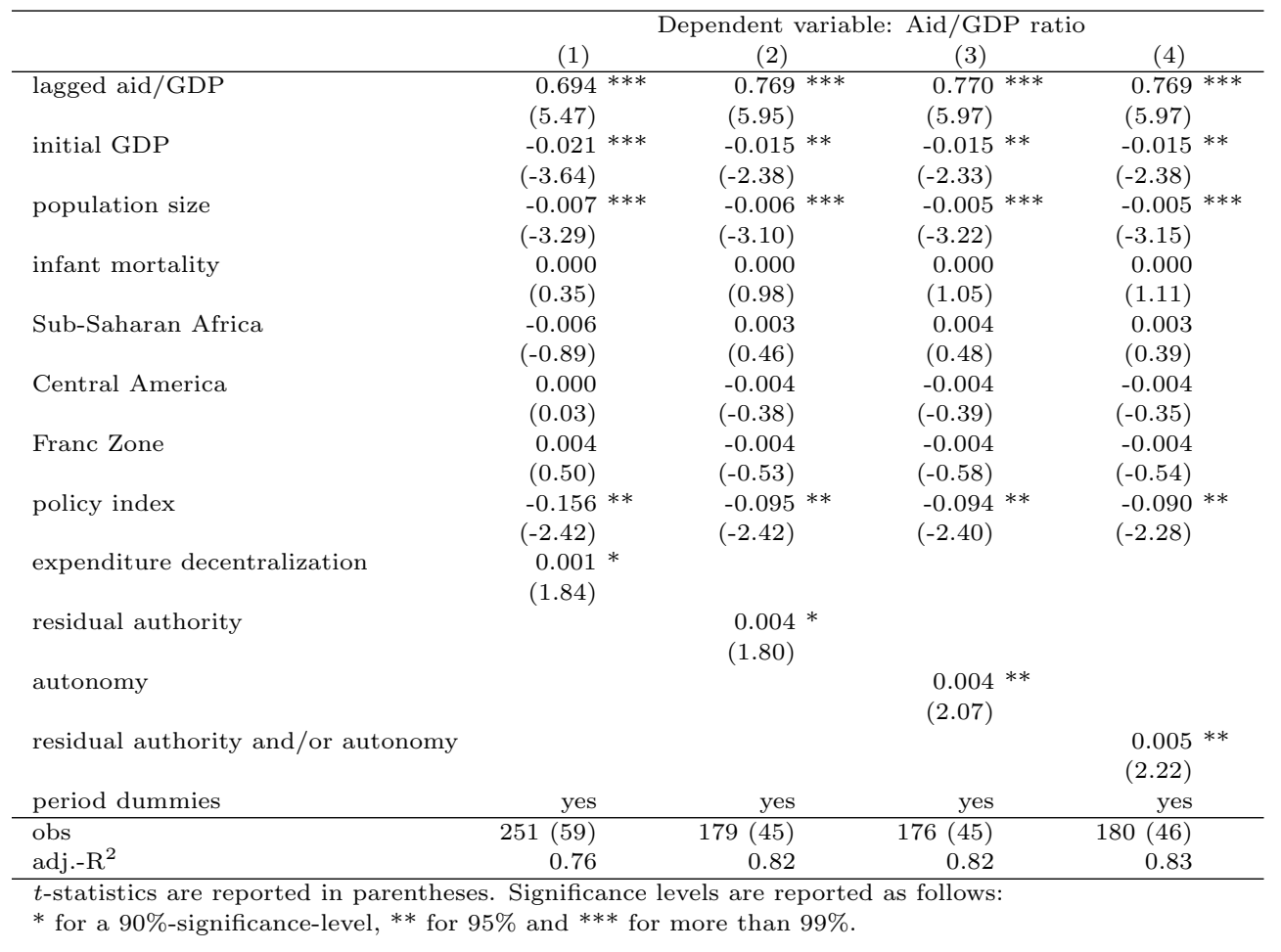

\section{$5 \quad$ Summary and Conclusions}

The effectiveness of foreign assistance is discussed extensively in scientific and public discussions. One issue that has been neglected in the empirical literature is the role of the federal structure of aid-receiving countries. The aim of our paper was to investigate whether aid effectiveness depends on the devolution of powers in developing countries.

For this purpose, we have estimated the impact of foreign assistance on growth by considering the interdependency between aid and various decentralization measures. Our estimations are based on a panel of 60 developing countries covering the period from 1966 to 1997 . We found that aid is less effective - or even harmful - in decentralized countries. Moreover, we investigated whether foreign assistance is allocated efficiently among developing countries, finding that decentralization has a positive impact on the amount of aid received.

Nevertheless, some additional remarks are necessary. The most important constraint of our crosscountry study is that we do not know much about the factual mechanisms of spending decisions of aid in developing countries. We can only assume that sub-national governments are involved in spending decisions in decentralized countries, and that our decentralization measures are good approximations. However, this is a common problem among cross-country studies of this kind. Another issue is that there might be differences between the various aims and sources of foreign 
assistance [see Ouattara and Strobl (2008)]. For instance, it may be easier for a local government to embezzle money from a general budget, as opposed to technical assistance, which is often directly supervised by the donor. A detailed study remains an issue for future research.

Another important issue is related to the appropriateness of our development measure. Following most studies on aid effectiveness, we refer to the growth of real per capita GDP as a measure of economic development. However, donor countries might be more interested in human development than economic development. Let us give an example for income data being a poor indicator of development: Angola is a country that has received up to 1 billion U.S. dollars (2004) in foreign aid per year. In recent years, the country faces (due to its oil exports) rapid economic growth, reaching a per capita GDP of nearly 4,000 U.S. dollars in 2007. Nevertheless, the situation of the poor continues to be unsatisfactory. In terms of aid per capita, Uganda is comparable to Angola, with both countries receiving about 30 U.S. dollars. However, Uganda has just a tenth of Angolan GDP per capita, but first-year infant mortality rates ( 80 per 1,000 live births) is just half of Angola's, with a value of 154 [Source: WDI, 2004]. Additionally, in terms of the Human Development Index (HDI) provided by the United Nations Development Program, Uganda is among the countries with medium human development (HDI 2005 score: 0.505), while Angola is among the group of countries with low human development (HDI 2005 score: 0.446 ). This example shows that income data - although commonly used as in our study - is not always appropriate in evaluating aid effectiveness. ${ }^{13}$ We have therefore experimented with indicators of human development as a dependent variable. Our results do not contradict our major findings. The fewer number of observations limit the robustness and validity in those regressions.

The policy implication of our findings is straightforward. Several national and international development agencies consider decentralization initiatives as a main part of their anti-poverty programs. Our study suggests that aid is less effective in decentralized countries. Therefore, it should be carefully considered how both instruments - foreign aid and decentralization - work together.

\footnotetext{
${ }^{13}$ Some studies, e.g., Boone (1996), consider alternative measures for development than income or GDP data. Boone estimates the aid/GDP ratio on growth of infant mortality, life expectancy, and primary schooling, finding no significant relationship with aid.
} 


\section{References}

Alesina, A., A. Devleeschauwer, W. Easterly, S. Kurlat, and R. Wacziarg (2003). Fractionalization. Journal of Economic Growth, 8(2), pp. 155-194.

Alesina, A. and D. Dollar (2000). Who gives foreign aid to whom and why? Journal of Economic Growth, 5(1), pp. 33-63.

Alesina, A. and B. Weder (2002). Do Corrupt Governments Receive Less Foreign Aid? American Economic Review, 92(4), pp. 1126-1137.

Ali, A. M. and H. S. Isse (2005). An Empirical Analysis of the Effect of Aid on Growth. International Advances in Economic Research, 11, pp. 1-11.

Alvi, A., D. Mukherjee, and E. K. Shukralla (2008). Aid, Policies, and Growth in Developing Countries: A New Look at the Empirics. Southern Economic Journal, 74(3), pp. 693-706.

Bacha, E. (1990). A three-gap model of foreign transfers and the GDP growth rate in developing countries. Journal of Development Economics, 32(2), pp. 279-296.

Banks, A. (2002). Cross-National Time-Series Data Archive. Bronx, NY: Databanks International.

Bardhan, P. (2002). Decentralization of Governance and Development. Journal of Economic Perspectives, 16, pp. 185-205.

Bardhan, P. and D. Mookherjee (2006). Decentralization and Accountability in Infrastructure Delivery in Developing Countries. Economic Journal, 116, pp. 101-127.

Bauer, P. (1972). Dissent on Development: Studies and Debated in Development Economics. Cambridge: Havard University Press.

Beck, N. and J. Katz (1995). What to do (and not to do) with time-series cross-section data. American Political Science Review, 89(3), pp. 634-647.

Boone, P. (1996). Politics and the effectiveness of foreign aid. European Economic Review, 40(1), pp. 289-329.

Brambor, T., W. R. Clark, and M. Golder (2006). Understanding interaction models: Improving empirical analyses. Political Analysis, 14, pp. 63-82.

Brueckner, J. K. (2000). Fiscal Decentralization in Developing Countries: The Effects of Local Corruption and Tax Evasion. Annals of Economics and Finance, 1(1), pp. 1-18.

Burnside, C. and D. Dollar (2000). Aid, Policies, and Growth. American Economic Review, 90, pp. $847-868$.

Burnside, C. and D. Dollar (2004a). Aid, Policies, and Growth: Reply. Economic Journal, 94(3), pp. $781-784$.

Burnside, C. and D. Dollar (2004b). Aid, Policies, and Growth: Revisiting the Evidence. World Bank Policy Research Working Paper No. 3251. 
Chang, C., E. Fernandez-Arias, and L. Serve'n (1998). Measuring aid flows: a new approach. World Bank Policy Research Working Paper No. 2050.

Chenery, H. B. and A. M. Strout (1966). Foreign Assistance and Economic Development. American Economic Review, 56(4), pp. 679-732.

Collier, P. and D. Dollar (2002). Aid allocation and poverty reduction. European Economic Review, $46(8)$, pp. $1475-1500$.

Dalgaard, C.-J. and H. Hansen (2001). On Aid, Growth and Good Politics. Journal of Development Studies, 37(6), pp. 17-41.

Dalgaard, C.-J., H. Hansen, and F. Tarp (2004). On the Empirics of Foreign Aid and Growth. Economic Journal, 114(496), pp. 191-216.

Davoodi, H. and H. Zou (1998). Fiscal Decentralisation and Economic Growth: A Cross Country Study. Journal of Urban Economics, 43, pp. 244-257.

Development Committee (2006). Strenghtening Bank Group Engagement on Governance and Anticurruption. Washington, D.C.: Joint Ministerial Committee of the Boards of Govenors of the World Bank and the International Monetary Fund on the Transfer of Real Resources to Developing Countries.

Domar, E. (1946). Capital Expansion, Rate of Growth, and Employment. Econometrica, 14, pp. $137-147$.

Dovern, J. and P. Nunnenkamp (2007). Aid and Growth Accelerations: An Alternative Approach to Assessing the Effectiveness of Aid. Kyklos, 60(3), pp. 359-383.

Dowling, J. M. and U. Hiemenz (1982). Aid, Savings and Growth in the Asian Region. Developing Economies, 21(1), pp. 3-13.

Easterly, W. (2003). Can Foreign Aid Buy Growth? Journal of Economic Perspectives, 17(3), pp. $23-48$.

Easterly, W., R. Levine, and D. Roodman (2004). Aid, Politics, and Growth: Comment. American Economic Review, 94(3), pp. 774-780.

Economides, G., S. Kalyvitis, and A. Philippopoulos (2008). Does Foreign Aid Distort Incentives and Hurt Growth? Theory and Evidence from 75 Aid-Recipient Countries. Public Choice, 134(3-4), pp. 463-488.

Enikolopov, R. and E. Zhuravskaya (2007). Decentralization and political institutions. Journal of Public Economics, 91, pp. 2261-2290.

Fan, C. S., C. Lin, and D. Treisman (2009). Political decentralization and corruption: Evidence from around the world. Journal of Public Economics, 93(1-2), pp. 14-34.

Friedman, M. (1958). Foreign Economic Aid: Means and Objectives. Yale Law Review, 47, pp. $24-38$. 
Guillaumont, P. and L. Chauvet (2001). Aid and Performance: A Reassessment. Journal of Development Studies, 37(6), pp. 66-92.

Hadi, A. S. (1994). A Modification of a Method for the Detection of Outliers in Multivariate Samples. Journal of the Royal Statistical Society, Series (B), 56, pp. 393-396.

Hansen, H. and F. Tarp (2000). Aid Effectiveness Disputed. Journal of International Development, 12(3), pp. 375-398.

Hansen, H. and F. Tarp (2001). Aid and Growth Regressions. Journal of Development Economics, $64(2)$, pp. 547-570.

Iimi, A. (2005). Decentralization and economic growth revisited: an empirical note. Journal of Urban Economics, 57(3), pp. 449-461.

Islam, M. (2005). Regime Changes, Economic Policies and the Effect of Aid on Growth. Journal of Development Studies, 41(8), pp. 1467-1492.

Jin, H., Y. Qian, and B. Weingast (2005). Regional decentralization and fiscal incentives: Federalism, Chinese style. Journal of Public Economics, 89(9-10), pp. 1719-1742.

Knack, S. and P. Keefer (1995). Institutions and Economic Performance: Cross-Country Test Using Alternative Institutional Measures. Economics and POlitics, 7(3), pp. 207-227.

Kourtellos, A., C. M. Tan, and X. Zhang (2007). Is the Relationship between Aid and Economic Growth Nonlinear? Journal of Macroeconomics, 29(3), pp. 515-540.

Lensink, R. and H. White (2001). Are There Negative Returns to Aid? Journal of Development Studies, 37(6), pp. 42-65.

Lessmann, C. and G. Markwardt (2008). One Size Fits all? Decentralization, Corruption, and the Monitoring of Bureaucrats. mimeo.

Levy, V. (1988). Aid and Growth in Sub-Saharan Africa: The Recent Experience. European Economic Review, 32(9), pp. 1777-1795.

Lin, J. and Z. Liu (2000). Fiscal decentralization and economic growth in China. Economic Development and Cultural Change, 49, pp. 1-21.

Litvack, J., J. Ahmad, and R. M. Bird (1998). Rethinking decentralization in developing countries. World Bank Sector Studies Series.

McGillivray, M., S. Feeny, N. Hermes, and R. Lensink (2006). Controversies over the impact of development aid: It works; it doesn't; it can, but that depends... Journal of International Development, 18, pp. 1031-1050.

Mosley, P., J. Hudson, and S. Horrell (1987). Aid, the Public Sector and the Market in Less Developed Countries. Economic Journal, 97, pp. 616-641.

Oates, W. (1993). Fiscal decentralization and Economic Development. National Tax Journal, 46(2), pp. 237-243. 
Oates, W. E. (1972). Fiscal Federalism. New York: Harcourt Brace Jovanovich.

Ouattara, B. and E. Strobl (2008). Aid, Policy and Growth: Does Aid Modality Matter? Review of World Economics, 144(2), pp. 347-365.

Papanek, G. (1972). The Effect of Aid and other Resource Transfers on Savings and Growth in Less Developed Countries. Economic Journal, 82(327), pp. 934-950.

Papanek, G. (1973). Aid, Foreign Private Investment, Savings and Growth in Less Developed Countries. Journal of Political Economy, 81(1), pp. 120-130.

Prud'homme, R. (1995). The Dangers of Decentralization. World Bank Research Observer, 10, 2 , pp. 201-220.

Rajan, R. G. and A. Subramanian (2008). Aid and Grwoth: What does the Cross-Country Evidence really show? Review of Economics and Statistics, 90(4), pp. 643-665.

Rodden, J. (2004). Comparative Federalism and Decentralization: On Meaning and Measurement. Comparative Politics, 36(4), pp. 481-500.

Roodman, D. M. (2007). The Anarchy of Numbers: Aid, Development, and Cross-country Empirics. World Bank Economic Review, 21(2), pp. 255-277.

Shleifer, A. and R. W. Vishny (1993). Corruption. Quarterly Journal of Economics, 108, pp. 599-611.

Svensson, J. (1999). Aid, Growth and Democracy. Economics and Politics, 11(3), pp. 275-297.

Swaroopa, V., S. Jhab, and A. S. Rajkumara (2000). Fiscal effects of foreign aid in a federal system of governance: The case of India. Journal of Public Economics, 77, pp. 307-330.

Tanzi, V. (1996). Fiscal Federalism and Decentralization: A Review of some Efficiency and Macroeconomic Aspects. In Proceedings of the Annual World Bank Conference on Development Economics 1995, pp. 295-316. Washington D.C.: The World Bank.

Thießen, U. (2003). Fiscal Decentralization and Economic Growth in High-Income OECD Countries. Fiscal Studies, 24, 3, pp. 237-274.

Thornton, J. (2007). Fiscal decentralization and economic growth reconsidered. Journal of Urban Economics, 61(1), pp. 64-70.

Treisman, D. (2002). Defining and Measuring Decentralization: A Global Perspective. Working paper university of california.

Voivodas, C. S. (1973). Exports, Foreign Capital Inflow and Economic Growth. Journal of International Economics, 3(4), pp. 337-349.

Weingast, B. (1995). The economic role of political institutions: Market-preserving federalism and economic development. Journal of Law, Economics and Organization, 11(1), pp. 1-31.

Woller, G. M. and K. Phillips (1998). Fiscal Decentralisation and LDC Economic Growth: An Empirical Investigation. Journal of Development Studies, 34, pp. 139-148. 
Wood, N. (2005). The shifting politics of foreign aid. International Affairs, 81(2), pp. 393-409.

Wooldridge, J. M. (2002). Econometric Analysis of Cross Section and Panel Data. Cambridge (MA): MIT Press.

Worldbank (2006). World Development Indicators 2006. Technical report.

Yilmaz, S. (2000). The Impact of Fiscal Decentralization on Macroeconomic Performance. In N. T. Association (editor), Proceedings of the 92nd Annual Conference on Taxation 1999, pp. 251-260. Washington D. C.

Zhang, T. and H. Zou (1998). Fiscal decentralization, public spending, and economic growth in China. Journal of Public Economics, 67(2), pp. 221-240. 
Table A.1: Data sources \& definitions

\begin{tabular}{|c|c|c|}
\hline Variable & Definition & Source \\
\hline real per capita GDP growth & $\begin{array}{l}\text { Growth rate of } 4 \text {-year-averaged GDP per capita in } 2000 . \$ \\
\text { prices }\end{array}$ & WDI 2006 \\
\hline Log of initial GDP & $\begin{array}{l}\text { Log of initial real GDP per capita in } 2000 \$ \text { prices at the start } \\
\text { of each period. }\end{array}$ & WDI 2006 \\
\hline ethnic fractionalization & $\begin{array}{l}\text { Ethnolinguistic fractionalization is computed as one minus } \\
\text { Herfindahl index of ethnolinguistic group shares, and reflects } \\
\text { the probability that two randomly selected individuals from } \\
\text { a population belonged to different groups. }\end{array}$ & Alesina et al. (2003) \\
\hline assassinations & $\begin{array}{l}\text { Assassinations: number of assassinations per million popula- } \\
\text { tion, see Banks (2002) for details. }\end{array}$ & Easterly et al. (2004) \\
\hline institutional quality & $\begin{array}{l}\text { Index of institutional quality by PRS Group's International } \\
\text { Country Risk Guide, see Knack and Keefer (1995) for details }\end{array}$ & Easterly et al. (2004) \\
\hline expenditure decentralization & $\begin{array}{l}\text { The degree of expenditure decentralization relates the sum of } \\
\text { sub-national (state \& local) government expenditures to total } \\
\text { government expenditures. }\end{array}$ & $\begin{array}{l}\text { IMF Government } \\
\text { nance Statistics }\end{array}$ \\
\hline aid/GDP & $\begin{array}{l}\text { Official development assistance (ODA) consists of net disbur- } \\
\text { sements of loans and grants made on concessional terms by } \\
\text { official agencies of the members of DAC and certain Arab } \\
\text { countries to promote economic development and welfare in } \\
\text { recipient economies listed as developing by DAC. ODA also } \\
\text { includes technical cooperation and assistance. Official aid to } \\
\text { transition and former Soviet countries is treated similar to } \\
\text { ODA. }\end{array}$ & WDI 2006 \\
\hline budget surplus & $\begin{array}{l}\text { The amount by which a government's income exceeds its spen- } \\
\text { ding over a period. }\end{array}$ & Easterly et al. (2004) \\
\hline Log of (1+inflation) & $\begin{array}{l}\text { Log of one plus the period averaged annual inflation rate (Las- } \\
\text { peyres). }\end{array}$ & WDI 2006 \\
\hline openness & Ratio between total trade (exports + imports) and GDP. & WDI 2006 \\
\hline policy index & $\begin{array}{l}\text { Index based on the performance of fiscal, monetary and trade } \\
\text { policies, see equation ( } 3 \text { ) for details. }\end{array}$ & own calculations \\
\hline Log of population & Log of total population. & WDI 2006 \\
\hline infant mortality & infant mortality rate per 1,000 live births. & WDI 2006 \\
\hline
\end{tabular}

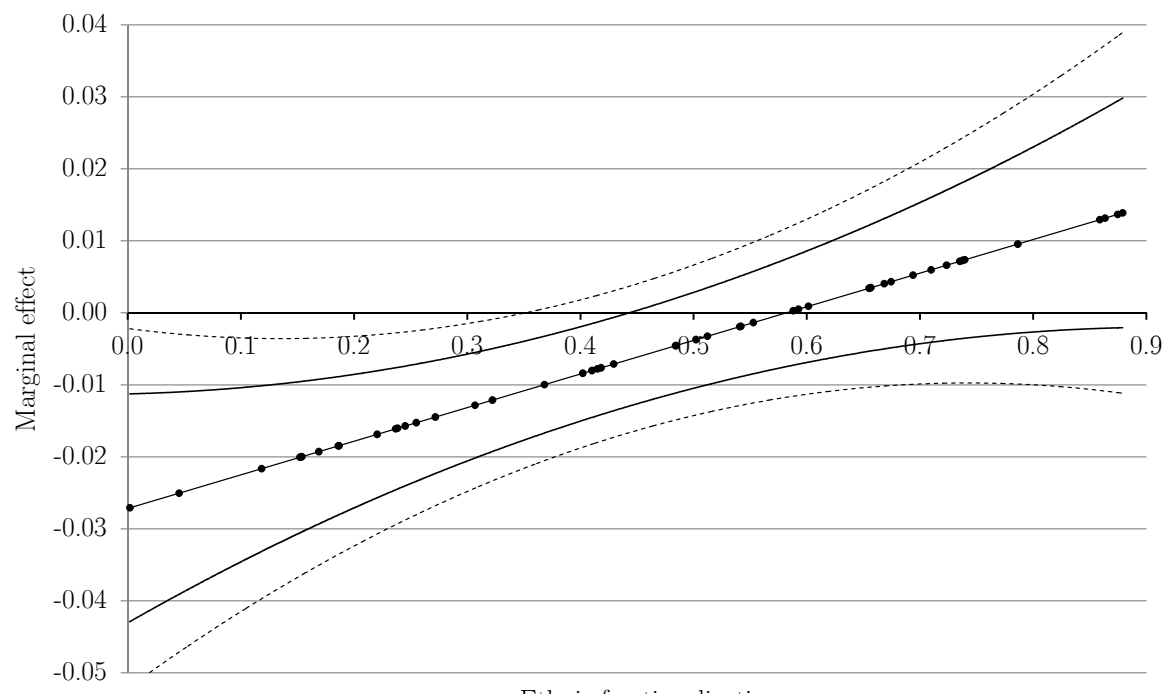

Ethnic fractionalization

— 0.90 confidence level $\quad$-..-- 0.99 confidence level

Figure 3: Marginal effect of assasinations on growth depending on ethnic fractionalizetion 
Table A.2: Summary statistics

\begin{tabular}{|c|c|c|c|c|c|}
\hline & Observations & Mean & Std. Dev. & Maximum & Minimum \\
\hline real per capita GDP growth & 403 & 0.06 & 0.13 & 0.57 & -0.37 \\
\hline initial GDP & 443 & 3683.49 & 2668.69 & 13586.40 & 330.37 \\
\hline ethnic fractionalization & 480 & 0.48 & 0.25 & 0.93 & 0.00 \\
\hline assassinations & 464 & 0.38 & 1.09 & 11.50 & 0.00 \\
\hline institutional quality & 480 & 4.88 & 1.67 & 8.23 & 1.60 \\
\hline expenditure decentralization & 480 & 15.73 & 13.85 & 50.71 & 1.53 \\
\hline aid/GDP & 409 & 0.05 & 0.06 & 0.41 & 0.00 \\
\hline budget surplus & 394 & -0.03 & 0.04 & 0.15 & -0.31 \\
\hline inflation & 397 & 91.19 & 468.37 & 6258.12 & -1.10 \\
\hline openness & 425 & 57.99 & 34.26 & 245.24 & 4.91 \\
\hline policy index & 348 & 0.02 & 0.04 & 0.06 & -0.25 \\
\hline population & 480 & $51 \times 10^{6}$ & $158 \times 10^{6}$ & $1.21 \times 10^{9}$ & $195 \times 10^{3}$ \\
\hline infant mortality & 350 & 66.98 & 40.27 & 189.00 & 5.80 \\
\hline
\end{tabular}

Table A.3: Estimation of policy indicators

\begin{tabular}{lc}
\hline \multicolumn{1}{c}{ Dependent variable: real GDP growth } \\
\hline initial GDP & 0.003 \\
& $(0.21)$ \\
ethnic fractionalization & $-0.053^{*}$ \\
& $(-1.92)$ \\
assassinations & $-0.028^{* * *}$ \\
& $(-2.89)$ \\
ethnic $\times$ assassinations & $0.048^{* *}$ \\
& $(2.38)$ \\
institutional quality & $0.009^{* *}$ \\
& $(2.35)$ \\
Sub-Saharan Africa & -0.026 \\
& $(-1.22)$ \\
East-Asia & $0.12^{* * *}$ \\
& $(9.95)$ \\
budget surplus & 0.225 \\
& $(1.09)$ \\
log $(1+$ inflation $)$ & $-0.066^{* * *}$ \\
openness & $(-5.19)$ \\
period dummies & -0.0003 \\
obs. & $(-1.05)$ \\
adj.-R ${ }^{2}$ & yes \\
\hline$t$-statistics are reported in parenthesis. \\
Significance levels are reported as follows: \\
and $* * *$ for more than $99 \%$. & 0.32 \\
\hline
\end{tabular}


Table A.4: Robustness check: time-variant decentralization measures

\begin{tabular}{|c|c|c|c|}
\hline & \multicolumn{3}{|c|}{ Dependent variable: real GDP growth } \\
\hline \multirow[t]{2}{*}{ initial GDP } & -0.031 & -0.030 & $-0.038^{*}$ \\
\hline & $(-1.59)$ & $(-1.62)$ & $(-1.95)$ \\
\hline \multirow[t]{2}{*}{ ethnic fractionalization } & -0.014 & -0.023 & -0.026 \\
\hline & $(-0.33)$ & $(-0.54)$ & $(-0.61)$ \\
\hline \multirow[t]{2}{*}{ assassinations } & -0.015 & -0.019 & -0.018 \\
\hline & $(-0.66)$ & $(-0.83)$ & $(-0.82)$ \\
\hline \multirow[t]{2}{*}{ ethnic $\times$ assassinations } & 0.012 & 0.016 & 0.014 \\
\hline & $(0.26)$ & $(0.35)$ & $(0.31)$ \\
\hline \multirow[t]{2}{*}{ institutional quality } & 0.009 & 0.005 & 0.006 \\
\hline & $(1.44)$ & $(0.83)$ & $(0.99)$ \\
\hline \multirow[t]{2}{*}{$\log (1+$ inflation $)$} & $-0.059^{* * *}$ & $-0.067 * * *$ & $-0.068^{* * *}$ \\
\hline & $(-3.62)$ & $(-4.20)$ & $(-4.12)$ \\
\hline \multirow[t]{2}{*}{ Sub-Saharan Africa } & -0.031 & -0.032 & -0.032 \\
\hline & $(-1.15)$ & $(-1.34)$ & $(-1.21)$ \\
\hline \multirow[t]{2}{*}{ East-Asia } & $0.110^{* * *}$ & $0.109 * * *$ & $0.103^{* * *}$ \\
\hline & $(4.48)$ & $(4.78)$ & $(4.40)$ \\
\hline \multirow[t]{2}{*}{ expenditure decentralization } & 0.000 & $0.002^{* * *}$ & $0.001 * *$ \\
\hline & $(0.51)$ & $(3.11)$ & $(2.17)$ \\
\hline \multirow[t]{2}{*}{ aid } & $-0.513^{* *}$ & 0.053 & -0.617 \\
\hline & $(-2.14)$ & $(0.24)$ & $(-1.07)$ \\
\hline \multirow[t]{2}{*}{$(\text { aid })^{2}$} & & & 2.828 \\
\hline & & & $(1.19)$ \\
\hline \multirow[t]{2}{*}{ aid $\times$ decentralization } & & $-0.048 * * *$ & -0.023 \\
\hline & & $(-5.09)$ & $(-0.89)$ \\
\hline \multirow{2}{*}{$(\text { aid })^{2} \times$ decentralization } & & & -0.131 \\
\hline & & & $(-0.85)$ \\
\hline period dummies & yes & yes & yes \\
\hline obs. & $188(57)$ & $188(57)$ & $188(57)$ \\
\hline $\operatorname{adj} .-R^{2}$ & 0.32 & 0.38 & 0.37 \\
\hline
\end{tabular}

Table A.5: Robustness check: interaction terms with squared aid

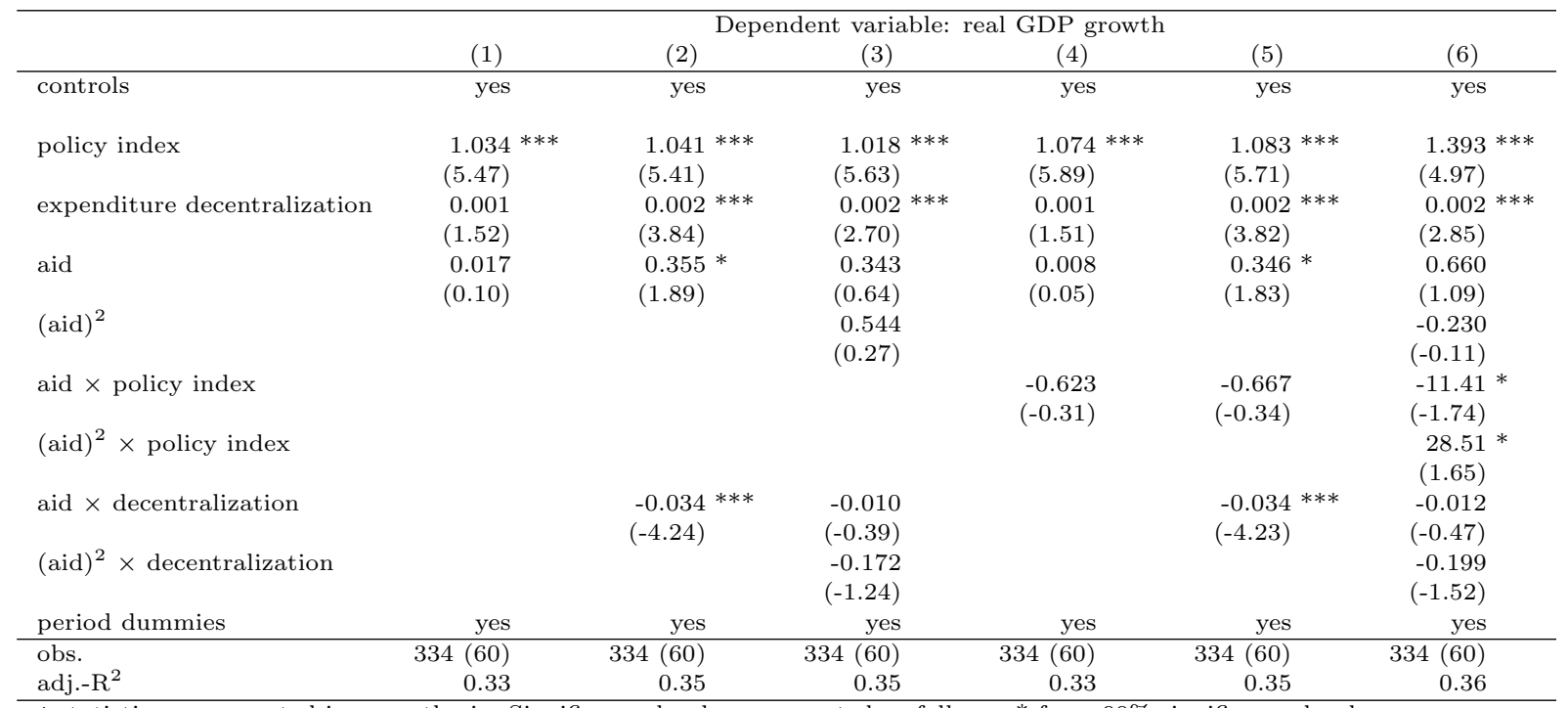

$t$-statistics are reported in parenthesis. Significance levels are reported as follows: ${ }^{*}$ for a $90 \%$-significance-level,

$* *$ for $95 \%$ and $* * *$ for more than $99 \%$. 


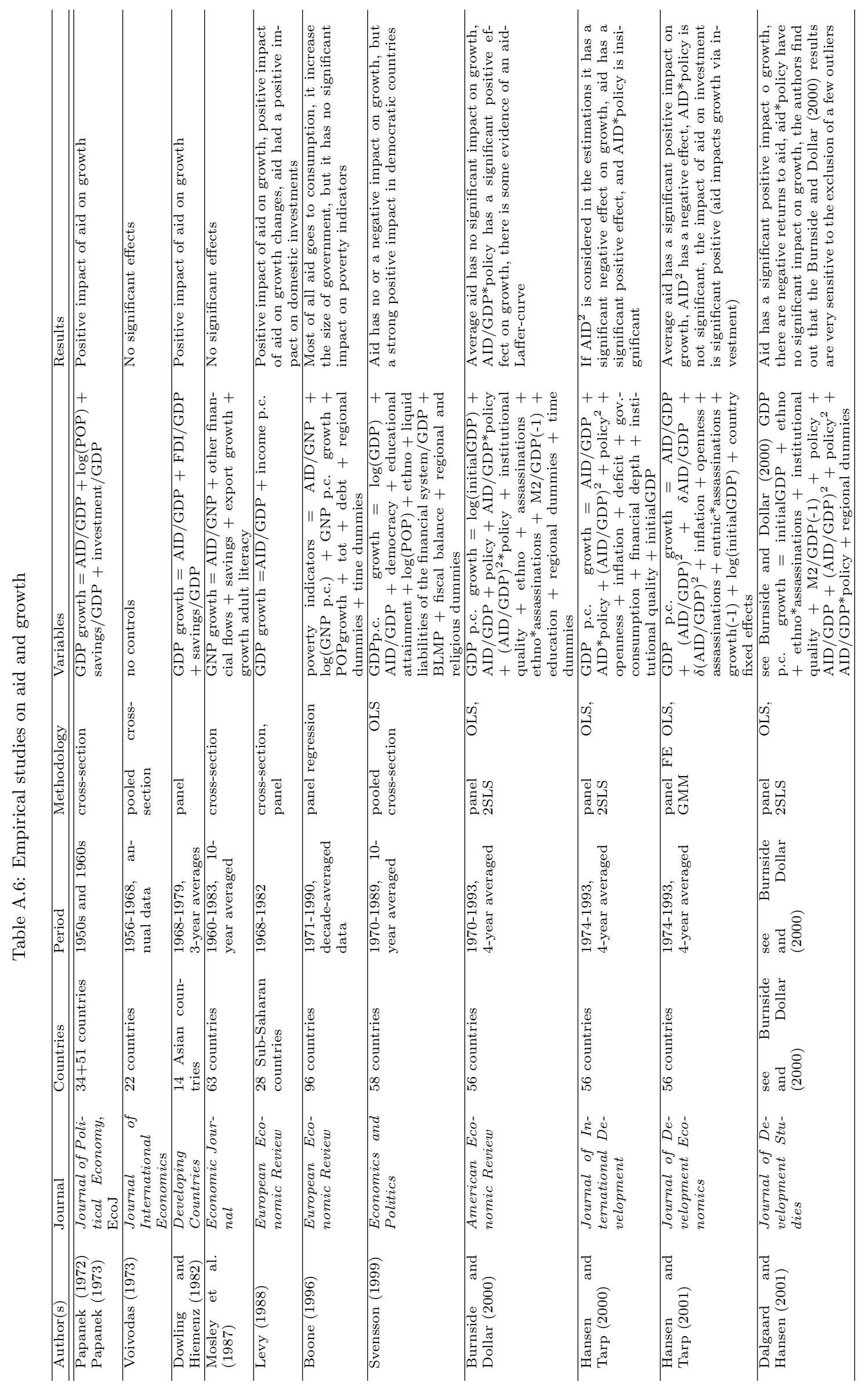




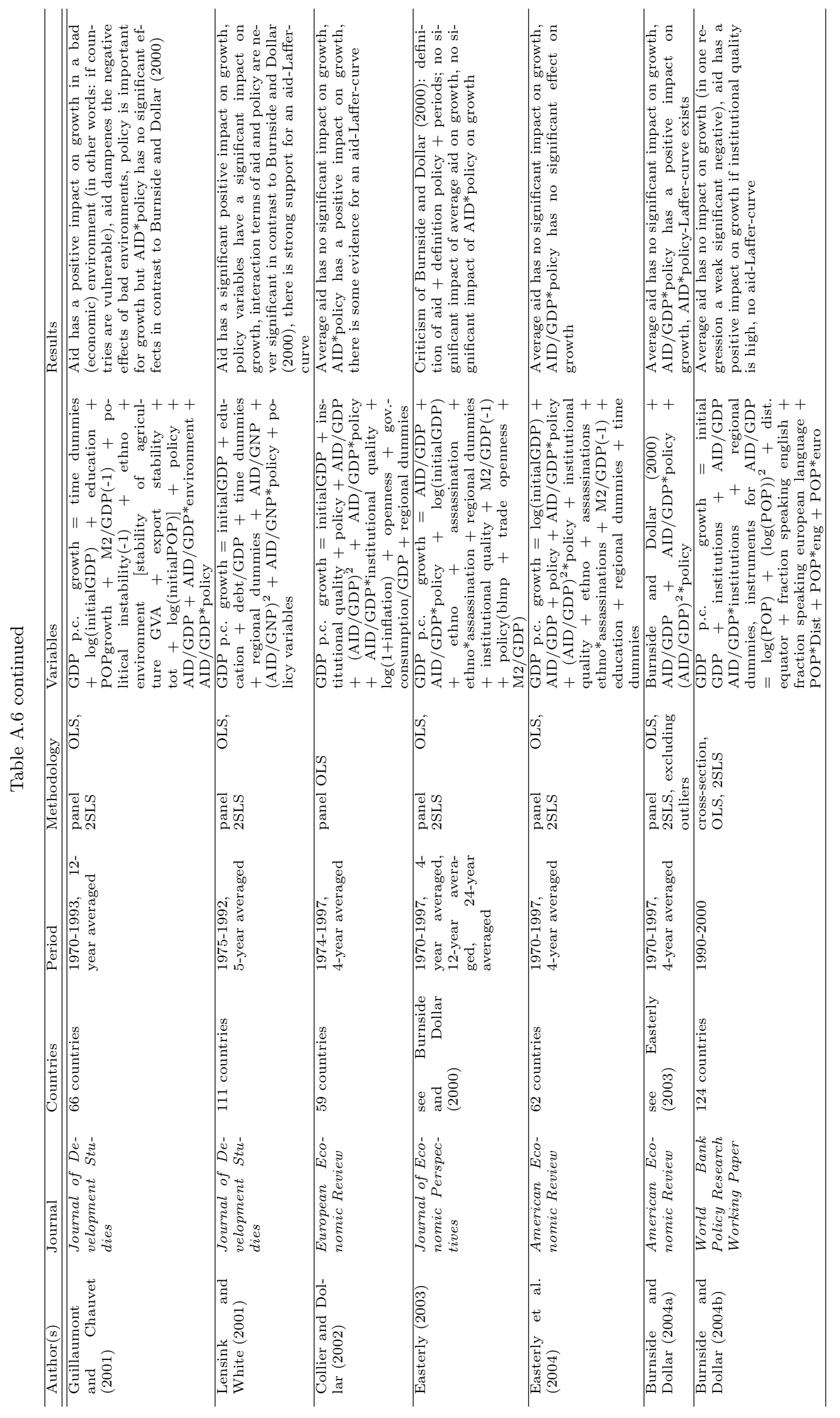




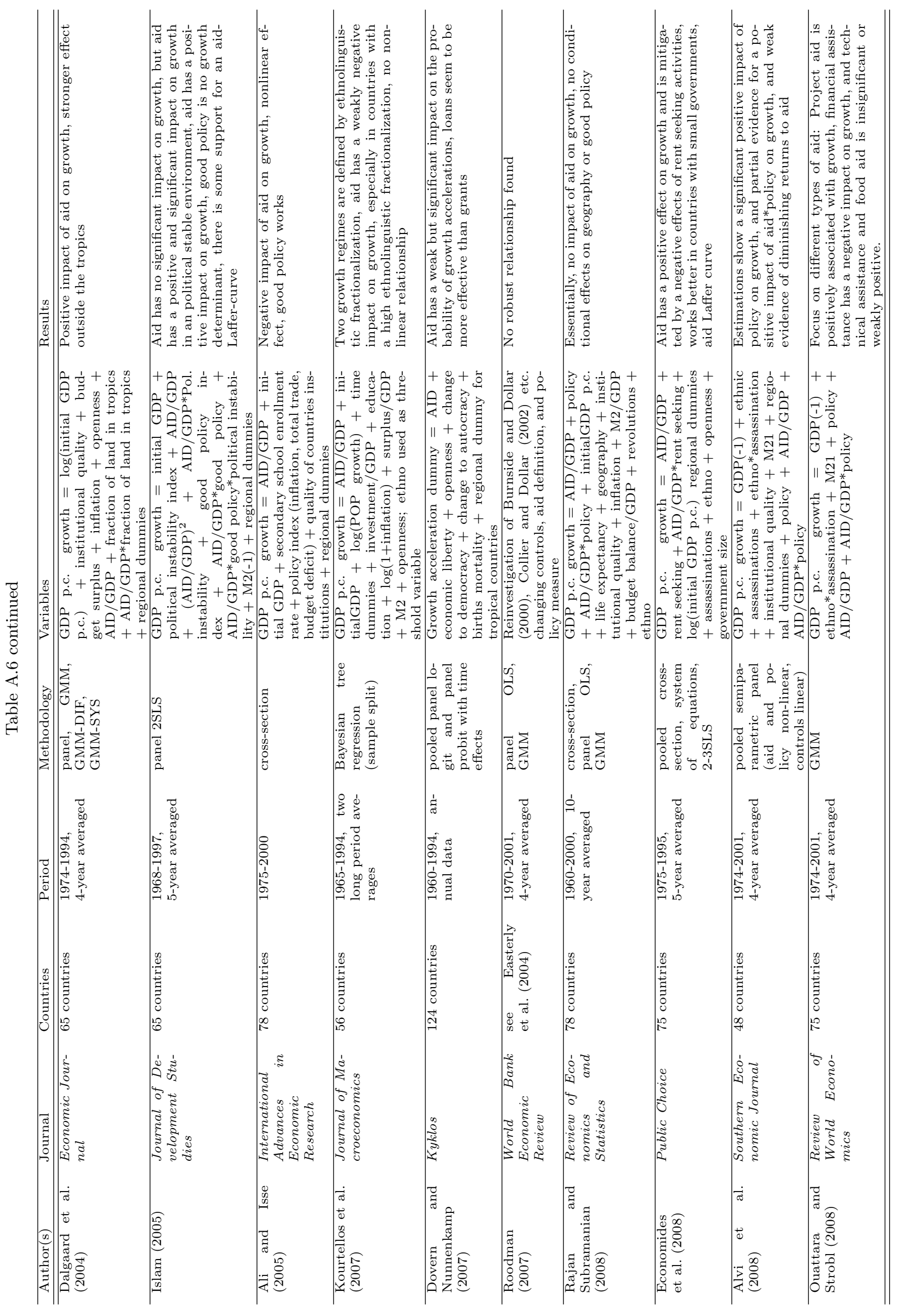




\section{CESifo Working Paper Series}

for full list see www.cesifo-group.org/wp

(address: Poschingerstr. 5, 81679 Munich, Germany, office@cesifo.de)

2741 Yan Dong and John Whalley, A Third Benefit of Joint Non-OPEC Carbon Taxes: Transferring OPEC Monopoly Rent, August 2009

2742 Valentina Bosetti, Carlo Carraro and Massimo Tavoni, Climate Change Mitigation Strategies in Fast-Growing Countries: The Benefits of Early Action, August 2009

2743 Christina Felfe, The Willingness to Pay for Job Amenities: Evidence from Mothers' Return to Work, August 2009

2744 Jörg Franke, Christian Kanzow, Wolfgang Leininger and Alexandra Väth, Effort Maximization in Asymmetric N-Person Contest Games, August 2009

2745 Bruno S. Frey and Paolo Pamini, Making World Heritage Truly Global: The Culture Certificate Scheme, August 2009

2746 Frank N. Caliendo, Is Social Security behind the Collapse of Personal Saving?, August 2009

2747 Caterina Liesegang and Marco Runkel, Corporate Income Taxation of Multinationals and Fiscal Equalization, August 2009

2748 Chrysovalantou Milliou and Apostolis Pavlou, Upstream Horizontal Mergers and Efficiency Gains, August 2009

2749 Rüdiger Pethig and Christian Wittlich, Interaction of Carbon Reduction and Green Energy Promotion in a Small Fossil-Fuel Importing Economy, August 2009

2750 Kai Carstensen, Oliver Hülsewig and Timo Wollmershäuser, Monetary Policy Transmission and House Prices: European Cross-country Evidence, August 2009

2751 Olaf Posch, Explaining Output Volatility: The Case of Taxation, August 2009

2752 Beatrice Scheubel, Daniel Schunk and Joachim Winter, Don't Raise the Retirement Age! An Experiment on Opposition to Pension Reforms and East-West Differences in Germany, August 2009

2753 Daniel G. Arce, Dan Kovenock and Brian Roberson, Suicide Terrorism and the Weakest Link, August 2009

2754 Mario Larch and Wolfgang Lechthaler, Comparative Advantage and Skill-Specific Unemployment, August 2009

2755 Horst Raff and Nicolas Schmitt, Buyer Power in International Markets, August 2009 
2756 Seppo Kari, Hanna Karikallio and Jukka Pirttilä, The Impact of Dividend Taxation on Dividends and Investment: New Evidence Based on a Natural Experiment, August 2009

2757 Mirco Tonin and Michael Vlassopoulos, Disentangling the Sources of Pro-social Behavior in the Workplace: A Field Experiment, August 2009

2758 Nicole Grunewald and Inmaculada Martínez-Zarzoso, Driving Factors of Carbon Dioxide Emissions and the Impact from Kyoto Protocol, August 2009

2759 Yu-Fu Chen and Michael Funke, Booms, Recessions and Financial Turmoil: A Fresh Look at Investment Decisions under Cyclical Uncertainty, August 2009

2760 Jan-Egbert Sturm and Jakob de Haan, Does Central Bank Communication really Lead to better Forecasts of Policy Decisions? New Evidence Based on a Taylor Rule Model for the ECB, August 2009

2761 Larry Karp, Sacrifice, Discounting and Climate Policy: Five Questions, August 2009

2762 Marianna Belloc and Samuel Bowles, International Trade, Factor Mobility and the Persistence of Cultural-Institutional Diversity, August 2009

2763 Charles Noussair and Fangfang Tan, Voting on Punishment Systems within a Heterogeneous Group, August 2009

2764 Birgit Bednar-Friedl and Karl Farmer, Internationally Coordinated Emission Permit Policies: An Option for Withdrawers from the Kyoto Protocol?, August 2009

2765 Pierre M. Picard and David E. Wildasin, Labor Market Pooling, Outsourcing and Labor Contracts, August 2009

2766 Stefan Voigt and Lorenz Blume, The Economic Effects of Federalism and Decentralization - A Cross-Country Assessment, August 2009

2767 David S. Jacks, Christopher M. Meissner and Dennis Novy, Trade Booms, Trade Busts, and Trade Costs, August 2009

2768 Mario Jametti and Thomas von Ungern-Sternberg, Hurricane Insurance in Florida, August 2009

2769 Alessandro Balestrino, Kind of Black: The Musicians' Labour Market in Italy, August 2009

2770 Yosr Abid Fourati and Cathal O’Donoghue, Eliciting Individual Preferences for Pension Reform, August 2009

2771 Christian Breuer and Chang Woon Nam, VAT on Intra-Community Trade and Bilateral Micro Revenue Clearing in the EU, August 2009

2772 Choudhry Tanveer Shehzad, Jakob De Haan and Bert Scholtens, Growth and Earnings Persistence in Banking Firms: A Dynamic Panel Investigation, August 2009 
2773 Erdal Yalcin, Uncertain Productivity Growth and the Choice between FDI and Export, August 2009

2774 Klaus Abberger, Wolfgang Nierhaus and Shynar Shaikh, Findings of the Signal Approach for Financial Monitoring in Kazakhstan, September 2009

2775 Sascha O. Becker, Francesco Cinnirella and Ludger Woessmann, The Trade-off between Fertility and Education: Evidence from before the Demographic Transition, September 2009

2776 Thomas Aronsson and Erkki Koskela, Optimal Income Taxation, Outsourcing and Policy Cooperation in a Dynamic Economy, September 2009

2777 Joel Slemrod, Old George Orwell Got it Backward: Some Thoughts on Behavioral Tax Economics, September 2009

2778 Cagri Seda Kumru and Athanasios C. Thanopoulos, Social Security Reform and Temptation, September 2009

2779 Alessandro Bucciol and Roel M. W. J. Beetsma, Inter- and Intra-generational Consequences of Pension Buffer Policy under Demographic, Financial and Economic Shocks, September 2009

2780 Eduardo Strube and Marcelo Resende, Complementarity of Innovation Policies in the Brazilian Industry: An Econometric Study, September 2009

2781 Henry Tulkens and Vincent van Steenberghe, "Mitigation, Adaptation, Suffering": In Search of the Right Mix in the Face of Climate Change, September 2009

2782 Maria L. Loureiro, Anna Sanz-de-Galdeano and Daniela Vuri, Smoking Habits: Like Father, Like Son, Like Mother, Like Daughter, September 2009

2783 Momi Dahan, Tehila Kogut and Moshe Shalem, Do Economic Policymakers Practice what they Preach? The Case of Pension Decisions, September 2009

2784 Eytan Sheshinski, Uncertain Longevity and Investment in Education, September 2009

2785 Nannette Lindenberg and Frank Westermann, How Strong is the Case for Dollarization in Costa Rica? A Note on the Business Cycle Comovements with the United States, September 2009

2786 Leif Danziger, Noncompliance and the Effects of the Minimum Wage on Hours and Welfare in Competitive Labor Markets, September 2009

2787 Gerlinde Fellner, Rupert Sausgruber and Christian Traxler, Testing Enforcement Strategies in the Field: Legal Threat, Moral Appeal and Social Information, September 2009

2788 Gabriel J. Felbermayr, Mario Larch and Wolfgang Lechthaler, Unemployment in an Interdependent World, September 2009 
2789 Sebastian G. Kessing, Federalism and Accountability with Distorted Election Choices, September 2009

2790 Daniel Gros, Global Welfare Implications of Carbon Border Taxes, September 2009

2791 Louis N. Christofides, Michael Hoy and Ling Yang, The Gender Imbalance in Participation in Canadian Universities (1977-2005), September 2009

2792 Jan K. Brueckner and Robert W. Helsley, Sprawl and Blight, September 2009

2793 Vidar Christiansen and Stephen Smith, Externality-correcting Taxes and Regulation, September 2009

2794 John Beirne, Guglielmo Maria Caporale, Marianne Schulze-Ghattas and Nicola Spagnolo, Global and Regional Spillovers in Emerging Stock Markets: A Multivariate GARCH-in-mean Analysis, September 2009

2795 Rüdiger Pethig and Frieder Kolleß, Asymmetric Capital-Tax Competition, Unemployment and Losses from Capital Market Integration, September 2009

2796 Ngo Van Long, Horst Raff and Frank Stähler, Innovation and Trade with Heterogeneous Firms, September 2009

2797 Margit Osterloh and Bruno S. Frey, Research Governance in Academia: Are there Alternatives to Academic Rankings?, September 2009

2798 Thiess Buettner and Clemens Fuest, The Role of the Corporate Income Tax as an Automatic Stabilizer, September 2009

2799 Annette Alstadsæter, Measuring the Consumption Value of Higher Education, September 2009

2800 Peter Friedrich, Chang Woon Nam and Janno Reiljan, Local Fiscal Equalization in Estonia: Is a Reform Necessary?, September 2009

2801 Evžen Kočenda and Jan Hanousek, State Ownership and Control in the Czech Republic, September 2009

2802 Michael Stimmelmayr, Wage Inequality in Germany: Disentangling Demand and Supply Effects, September 2009

2803 Biswa N. Bhattacharyay, Towards a Macroprudential Surveillance and Remedial Policy Formulation System for Monitoring Financial Crisis, September 2009

2804 Margarita Katsimi, Sarantis Kalyvitis and Thomas Moutos, "Unwarranted" Wage Changes and the Return on Capital, September 2009

2805 Christian Lessmann and Gunther Markwardt, Aid, Growth and Devolution, September 2009 